This item was submitted to Loughborough's Research Repository by the author.

Items in Figshare are protected by copyright, with all rights reserved, unless otherwise indicated.

\title{
Vanadium(v) tetra-phenolate complexes: synthesis, structural studies and ethylene homo-(co-) polymerization capability
}

PLEASE CITE THE PUBLISHED VERSION

http://dx.doi.org/10.1039/c5ra20177b

\section{PUBLISHER}

(c) The Authors. Published by the Royal Society of Chemistry.

\section{VERSION}

AM (Accepted Manuscript)

\section{PUBLISHER STATEMENT}

This work is made available according to the conditions of the Creative Commons Attribution-NonCommercialNoDerivatives 4.0 International (CC BY-NC-ND 4.0) licence. Full details of this licence are available at: https://creativecommons.org/licenses/by-nc-nd/4.0/

\section{LICENCE}

CC BY-NC-ND 4.0

\section{REPOSITORY RECORD}

Redshaw, Carl, Mark J. Walton, Mark R.J. Elsegood, Timothy J. Prior, and Kenji Michiue. 2019. "Vanadium(v) Tetra-phenolate Complexes: Synthesis, Structural Studies and Ethylene Homo-(co-) Polymerization Capability". figshare. https://hdl.handle.net/2134/20130. 


\section{Vanadium(V) tetra-phenolate complexes: Synthesis, structural studies and ethylene homo-(co-)polymerization capability}

Carl Redshaw, ${ }^{\mathrm{a}^{*}}$ Mark J. Walton, ${ }^{\mathrm{b}}$ Mark R.J. Elsegood, ${ }^{\mathrm{c}}$ Timothy J. Prior $^{\mathrm{a}}$ and Kenji Michiue ${ }^{\mathrm{d}}$

${ }^{a}$ Department of Chemistry, University of Hull, Hull, HU6 7RX, U.K.

${ }^{b}$ Energy Materials Laboratory, School of Chemistry, University of East Anglia, Norwich, NR4 7TJ, U.K.

c Chemistry Department, Loughborough University, Loughborough, Leicestershire, LE11 3TU, U.K.

${ }^{d}$ Process Technology Center, Mitsui Chemicals Inc., 580-32 Nagaura, Sodegaura, Chiba 2990265, Japan.

Abstract: Reaction of the ligand $\alpha, \alpha, \alpha^{\prime}, \alpha^{\prime}$-tetrakis(3,5-di-tert-butyl-2-hydroxyphenyl)-p-xylene ( $p$ $\left.\mathrm{L}^{1} \mathrm{H}_{4}\right)$ with two equivalents of $\left[\mathrm{VO}(\mathrm{OR})_{3}\right](\mathrm{R}=n \mathrm{Pr}, t \mathrm{Bu})$ in refluxing toluene afforded, after work-up, the complexes $\left\{[\mathrm{VO}(\mathrm{OnPr})(\mathrm{THF})]_{2}\left(\mu-p-\mathrm{L}^{1}\right)\right\} \cdot 2(\mathrm{THF})(\mathbf{1} \cdot 2(\mathrm{THF}))$ or $\left\{[\mathrm{VO}(\mathrm{OtBu})]_{2}\left(\mu-p-\mathrm{L}^{1}\right)\right\} \cdot 2 \mathrm{MeCN}$ $(2 \cdot 2 \mathrm{MeCN})$, respectively in moderate to good yield. A similar reaction using the meta ligand, namely $\alpha, \alpha, \alpha^{\prime}, \alpha^{\prime}$-tetrakis(3,5-di-tert-butyl-2-hydroxyphenyl)-m-xylene $\quad\left(m-\mathrm{L}^{2} \mathrm{H}_{4}\right)$ afforded the complex $\left\{[\mathrm{VO}(\mathrm{OnPr})(\mathrm{THF})]_{2}\left(\mu-p-\mathrm{L}^{2}\right)\right\}(3)$. Use of $\left[\mathrm{V}\left(\mathrm{N} p-\mathrm{R}^{1} \mathrm{C}_{6} \mathrm{H}_{4}\right)(t \mathrm{BuO})_{3}\right]\left(\mathrm{R}^{1}=\mathrm{Me}, \mathrm{CF}_{3}\right)$ with $p-\mathrm{L}^{1} \mathrm{H}_{4}$ led to the isolation of the oxo-imido complexes $\left\{[\mathrm{VO}(t \mathrm{BuO})]\left[\mathrm{V}\left(\mathrm{N} p-\mathrm{R}^{1} \mathrm{C}_{6} \mathrm{H}_{4}\right)(t \mathrm{BuO})\right]\left(\mu-p-\mathrm{L}^{1}\right)\right\}\left(\mathrm{R}^{1}=\mathrm{Me}\right.$, 4. $\mathrm{CH}_{2} \mathrm{Cl}_{2} ; \mathrm{CF}_{3}$, 5. $\left.\mathrm{CH}_{2} \mathrm{Cl}_{2}\right)$, whereas use of $\left[\mathrm{V}\left(\mathrm{Np}-\mathrm{R}^{1} \mathrm{C}_{6} \mathrm{H}_{4}\right) \mathrm{Cl}_{3}\right]\left(\mathrm{R}^{1}=\mathrm{Me}, \mathrm{CF}_{3}\right)$ in combination with 
$\mathrm{Et}_{3} \mathrm{~N} / p-\mathrm{L}^{1} \mathrm{H}_{4}$ or $p$ - $\mathrm{L}^{1} \mathrm{Na}_{4}$ afforded the diimido complexes $\left\{\left[\mathrm{V}\left(\mathrm{N} p-\mathrm{MeC}_{6} \mathrm{H}_{4}\right)(\mathrm{THF}) \mathrm{Cl}\right]_{2}(\mu-p-\right.$ $\left.\left.\mathrm{L}^{1}\right)\right\}$-4toluene (6-4toluene) or $\left\{\left[\mathrm{V}\left(\mathrm{N} p-\mathrm{CF}_{3} \mathrm{C}_{6} \mathrm{H}_{4}\right)(\mathrm{THF}) \mathrm{Cl}\right]_{2}\left(\mu-p-\mathrm{L}^{1}\right)\right\}$ (7). For comparative studies, the complex $\left[(\mathrm{VO})(\mu-\mathrm{OnPr}) \mathrm{L}^{3}\right]_{2}(\mathbf{8})$ has also been prepared via the interaction of $\left[\mathrm{VO}(n \mathrm{PrO})_{3}\right]$ and $2-(\alpha-$ (2-hydroxy-3,5-di-tert-butylphenyl)benzyl)-4,6-di-tert-butylphenol $\left(\mathrm{L}^{3} \mathrm{H}_{2}\right)$. The crystal structures of 1.2THF, 2-2MeCN, 3, 4. $\mathrm{CH}_{2} \mathrm{Cl}_{2}, 5 \cdot \mathrm{CH}_{2} \mathrm{Cl}_{2}, \mathbf{6} \cdot 4$ toluene-thf, 7 and $\mathbf{8}$ have been determined. Complexes $\mathbf{1}$ - $\mathbf{3}$ and $\mathbf{5}$ - $\mathbf{8}$ have been screened as pre-catalysts for the polymerization of ethylene in the presence of a variety of co-catalysts (with and without a re-activator), including DMAC (dimethylaluminium chloride), DEAC (diethylaluminium chloride), EADC (ethylaluminium dichloride) and EASC (ethylaluminium sesquichloride) at various temperatures and for the copolymerization of ethylene with propylene; results are compared versus the benchmark catalyst [VO(OEt)Cl 2 . In some cases, activities as high as $243,400 \mathrm{~g} / \mathrm{mmolV} . \mathrm{h}$ (30.43 Kg PE/mmolV.h.bar) were achievable, whilst it also proved possible to obtain higher molecular weight polymers (in comparable yields to the use of $\left.\left[\mathrm{VO}(\mathrm{OEt}) \mathrm{Cl}_{2}\right]\right)$. In all cases with dimethylaluminium chloride (DMAC)/ethyltrichloroacetate (ETA) activation, the activities achieved surpassed those of the benchmark catalyst. In the case of the co-polymerization of ethylene with propylene, Complexes 1 3 and 5 - 8 showed comparable or higher molecular weight than $\left[\mathrm{VO}(\mathrm{OEt}) \mathrm{Cl}_{2}\right]$ with comparable catalytic activities or higher in the case of the imido complexes $\mathbf{6}$ and $\mathbf{7 .}$

Keywords: Vanadium; tetra-phenolate; polyethylene; ethylene/propylene copolymer; crystal structures. 
Introduction: Interest in the use of group $\mathrm{V}$ metal complexes as potential components in new catalytic systems for the production of new polymers from $\alpha$-olefins continues to attract both academic and industrial interest. [1] This is in-part driven by the need for new IP in emerging economies such as China and India. In the case of vanadium, interest is further stimulated by the ability to achieve high activities and conduct co- and ter-polymerizations. [2] Notable recent successes have been achieved, which have made use of a variety of ligand sets including phenoxyimines, mono-dentate aryloxides, $\quad \beta$-enaminoketonato and phenoxyphosphine/phosphineoxides. [3] In our previous work, we have observed very high activities when employing chelating phenoxide ligands, including the use of calix[ $n]$ arenes, as well as di-/tri-phenols. [4] With this in mind, we were keen to explore other ligand systems that were capable of simultaneously binding to more than one metal centre. A new family of tetraphenols was recently reported by Tang et al. [5], which have since been exploited by the group of Wu to prepare multi alkali-metal complexes capable of the ring opening polymerization (ROP) of $L$-lactide, [6] and by us to afford niobium-based complexes capable of the ROP of $\varepsilon$-caprolactone. [7] Herein, we describe the synthesis and molecular structures of a series of vanadyl complexes of this ligand family (shown in Scheme 1), and investigate their polymerization catalysis behavior towards ethylene and ethylene/propylene under a variety of conditions. Extremely high catalytic activities, of the order of 243,400 g/mmolV.h at 8 bar ethylene (30.43 Kg PE/mmolV.h.bar), were found to be achievable for these systems which, combined with their ability to afford reasonably high molecular weight products at high temperature, suggests that such systems could be of industrial interest. Indeed, to the best of our knowledge, these are the highest catalytic activities reported to-date for vanadium-based systems for ethylene polymerization under robust conditions. We note though that these high activities, versus related systems, can be ascribed to the use of the high pressures ( 8 bar) employed herein. For 
example, the phosphine-phenoxide complex $\left\{\left[2,4-(t \mathrm{Bu})_{2}-6-\mathrm{PPh}_{2} \mathrm{C}_{6} \mathrm{H}_{2} \mathrm{O}\right] \mathrm{VCl}_{2}(\mathrm{THF})_{2}\right\}$ can achieve an activity of $41.3 \mathrm{KgPE} / \mathrm{mmolV}$.h at $1 \mathrm{bar}$. [3d] Of the other highly active vanadium systems known (see scheme 2), the coordination at the metal tends to be a combination of nitrogen (in the form of either an organimido group of an imine linkage) and oxygen (mono- or bi-dentate phenoxide ligation) or, more recently, calix[n]arene derived ligation. [3, 4] High molecular weight polyethylene is an attractive product given its favorable mechanical and physical properties, though there can be issues with regard to processing. [8] We note that industrially, the co-polymerization of ethylene with higher olefins has been successfully achieved by employing group IV-based constrained geometry catalysts. For example, Dow Chemicals has also utilized complexes bearing imino-enamido or pyridyl-amido ligation for ethylene/ $\alpha$-olefin copolymerization and polyolefin block copolymer formation. $[9,10]$ However, we note that only a limited number of vanadium-based systems have been reported for ethylene/propylene co-polymerization. [4b-d, 11] 


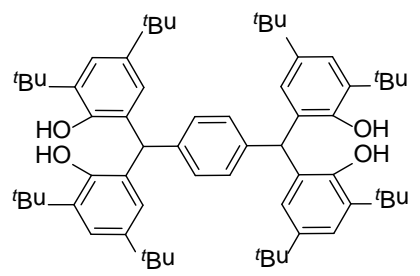

$\mathrm{L}^{1} \mathrm{H}_{4}$

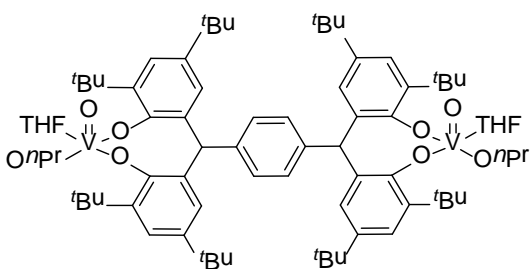

(1)

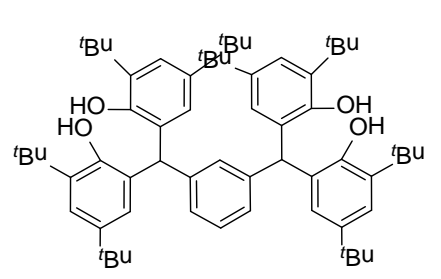

$\mathrm{L}^{2} \mathrm{H}_{4}$

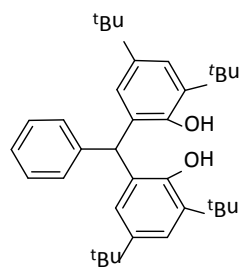

$\mathrm{L}^{3} \mathrm{H}_{2}$

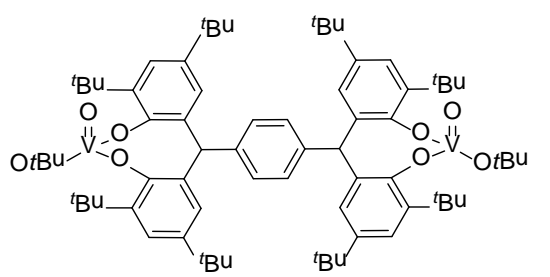

(2)

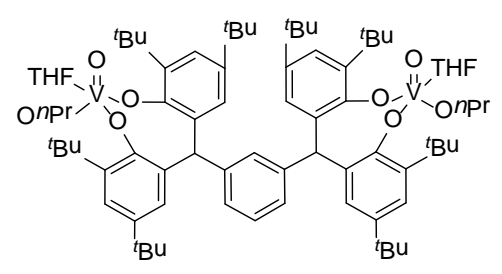

(3)

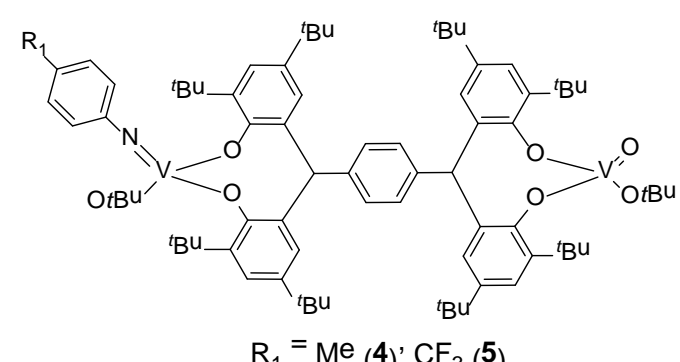

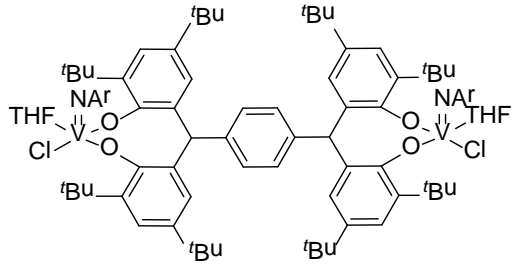

$\mathrm{Ar}^{\mathrm{r}}=p^{-}$t잉 (6)' $p^{-} \mathrm{CF}_{3} \mathrm{C}_{6} \mathrm{H}_{4}\left(\mathbf{7}^{7}\right)$

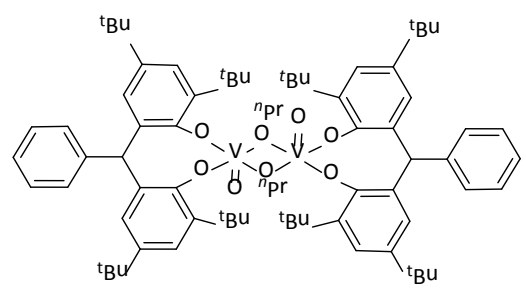

(8)

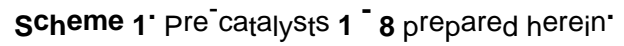




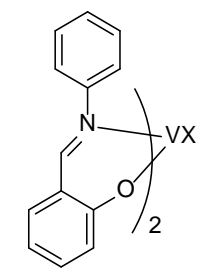

Mitsui chemicals corp. $65,000 \mathrm{Kg} / \mathrm{mol}$ V.h.bar
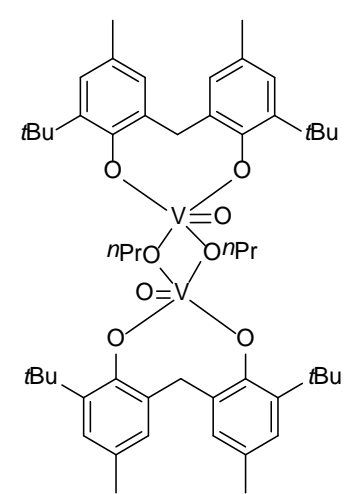

Our group $157,000 \mathrm{Kg} / \mathrm{mol}$ V.h.bar (23.9 KgPE/mmol V.h.bar) ${ }^{b}$

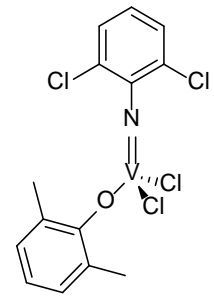

Nomura $55,800 \mathrm{Kg} / \mathrm{mol}$ V.h (7.0 KgPE/mmol V.h.bar) ${ }^{c}$

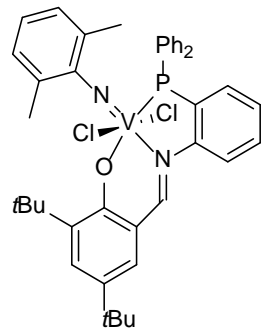

Li $133,800 \mathrm{Kg} / \mathrm{mol}$ V.h (16.7 KgPE/mmol V.h.bar) ${ }^{d}$

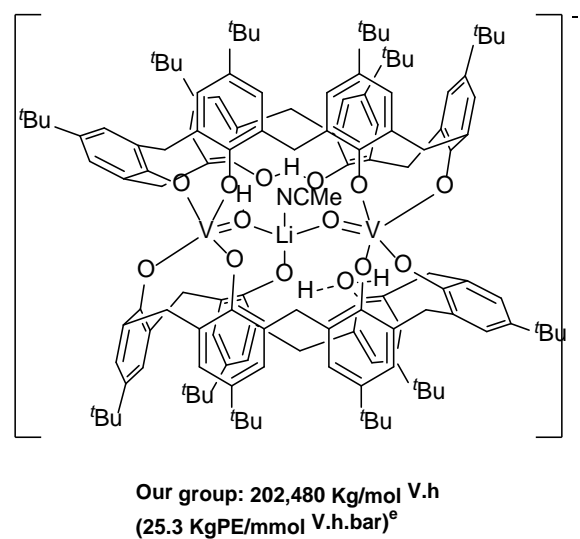

Scheme 2. Known, highly active vanadium-based ethylene polymerization pre-catalysts. [3, 4] Conditions employed: ${ }^{a}$

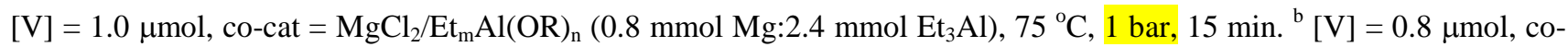
cat $=\mathrm{Me}_{2} \mathrm{AlCl}(2 \mathrm{mmol})$, ETA $(2 \mathrm{mmol}), 80^{\circ} \mathrm{C}, 7 \mathrm{bar}, 15 \mathrm{~min} .{ }^{\mathrm{C}}[\mathrm{V}]=0.05 \mu \mathrm{mol}$, co-cat $=\mathrm{Et}_{2} \mathrm{AlCl}\left(2000\right.$ equiv.), $0{ }^{\circ} \mathrm{C}, 8$ bar, 10 min. ${ }^{\mathrm{d}}[\mathrm{V}]=0.1 \mu \mathrm{mol}$, co-cat $=\mathrm{Et}_{2} \mathrm{AlCl}(0.05 \mathrm{M}), 75{ }^{\circ} \mathrm{C}, 8 \mathrm{bar}, 10 \mathrm{~min} .{ }^{\mathrm{e}}[\mathrm{V}]=0.005 \mu \mathrm{mol}$, co-cat $=\mathrm{Me}_{2} \mathrm{AlCl}$ (20000 equiv.), ETA (20000 equiv.), $80{ }^{\circ} \mathrm{C}, 8 \mathrm{bar}, 30 \mathrm{~min}$.

\section{Results and Discussion}

Synthesis and structure of $p-L^{1} H_{4}$ derived vanadyl complexes: The ligand $p-\mathrm{L}^{1} \mathrm{H}_{4}$ was synthesized following the reported literature method. [5] The compounds $\{[\mathrm{VO}(\mathrm{O}$ $\left.n \mathrm{Pr})(\mathrm{THF})]_{2}\left(\mu-p-\mathrm{L}^{1}\right)\right\}(\mathbf{1})$ and $\left.\left\{[\mathrm{VO}(\mathrm{OtBu})]_{2}\left(\mu-p-\mathrm{L}^{1}\right)\right\}(\mathbf{2})\right)$ were synthesized in moderate to good yield (45 - $75 \%$ ) via the treatment of $\mathrm{L}^{1} \mathrm{H}_{4}$ with a slight excess (2.1 equiv.) of [VO(OR) $)_{3}$. If the reaction is conducted in THF, then this solvent can act as a ligand as in $\mathbf{1}$, vide infra. Conducting 
the reaction in toluene and avoiding the use of THF in the work-up affords THF-free products, as in 2. In either case, the reaction proceeds with loss of two equivalents of alcohol per vanadium center. In the case of $\mathbf{1}(\mathrm{R}=n \mathrm{Pr})$, crystals suitable for a single crystal X-ray diffraction study were grown by slow diffusion of light petroleum into THF; the crystal structure is presented in Figure 1 (for ORTEP diagram see Figure S1 in the ESI). Each vanadyl center is present in trigonal bipyramidal geometry, and bears an $n$-propoxide ligand with the fifth position trans to the oxo group occupied by a THF molecule. The two sets of di-phenolates across the central phenyl ring are arranged in a trans fashion related by an inversion center. The bond lengths and angles are given in the caption to Figure 1, and are typical and similar to the other vanadium complexes in trigonal bipyramidal geometry. [12] An 8-membered metallocycle is formed at each end of the tetra-phenolate, with each adopting the chair-boat conformation. The bite angle of the chelate is $111.73(7)^{\circ}$, which is somewhat larger than that found in the mononuclear vanadyl complex $\left\{\mathrm{VOCl}\left[2,2^{\prime}-\mathrm{CH}_{2}\left(4-\mathrm{Me}-6-t \mathrm{BuC}_{6} \mathrm{H}_{2} \mathrm{O}\right)_{2}\right]\right\}\left(106.9(2){ }^{\circ}\right)$ and the dimeric complex $\left\{\mathrm{VO}(\mathrm{OnPr})\left(2,2^{\prime}-\mathrm{CH}_{3} \mathrm{CH}\left[4,6-(t \mathrm{Bu})_{2} \mathrm{C}_{6} \mathrm{H}_{2}\right)_{2}\right]\right\}\left(94.49(10)^{\circ}\right)$. [4, 13] In the IR spectra for $\mathbf{1}$ and 2 , a strong band at $c a .990 \mathrm{~cm}^{-1}$ is assigned to the $v(\mathrm{~V}=\mathrm{O})$ mode.

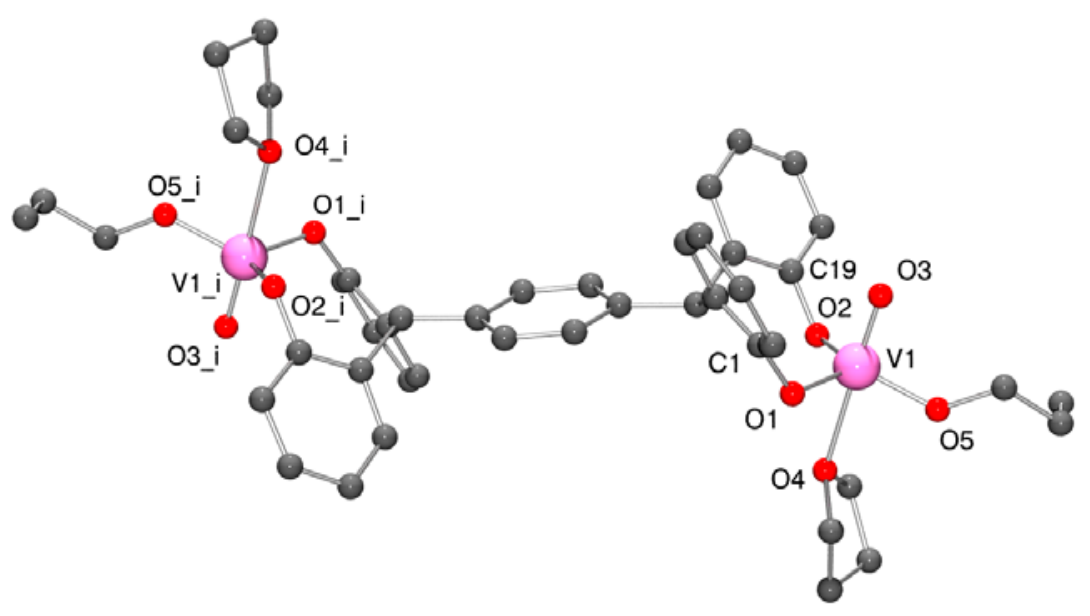

Figure 1. Representation of the centro-symmetric molecular structure of complex $\mathbf{1}$ in the solid state, indicating the atom numbering scheme. tert-Butyl groups, hydrogen atoms, and unbound solvent molecules have been removed for clarity. Selected bond lengths $(\AA)$ and angles $\left(^{\circ}\right)$ : V1- 
O3 1.5871(14), V1-O5 1.7878(15), V1-O2 1.8187(15), V1-O1 1.8256(16), V1-O4 2.3307(13), O3-V1-O5 100.20(7), O3-V1-O2 100.05(7), O5-V1-O2 119.29(7), O3-V1-O1 99.63(7), O5V1-O1 120.16(7), O2-V1-O1 111.73(7), O3-V1-O4 178.12(7), O5-V1-O4 78.36(6), O2-V1O4 81.73(6), O1-V1-O4 80.16(6). Symmetry operation used to generate equivalent atoms: $\mathrm{i}=$ $1-x,-y,-z$.

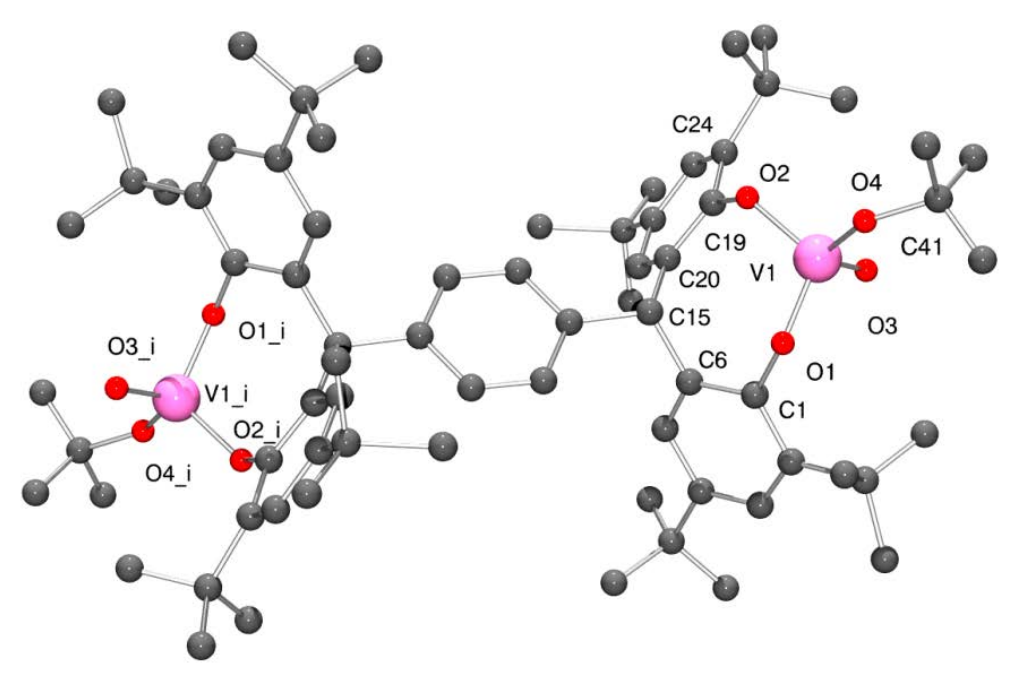

Figure 2. Representation of the centro-symmetric molecular structure of complex $\mathbf{2}$ in the solid state, indicating the atom numbering scheme. Hydrogen atoms, and unbound solvent molecules have been removed for clarity. Selected bond lengths $(\AA)$ and angles $\left(^{\circ}\right)$ : O1-V1 1.725(6), O2V1 1.786(5), O3-V1 1.547(6), O4-V1 1.682(7), O3-V1-O4 112.4(4), O3-V1-O1 106.8(3), O4V1-O1 110.1(3), O3-V1-O2 106.1(3), O4-V1-O2 109.3(3), O1-V1-O2 112.0(2). Symmetry operation used to generate equivalent atoms: $i=1-x, 1-y,-z$.

In complex 2, each vanadyl centre is bound by the bi-dentate di-phenolate, forming an 8membered metallocycle with a bite angle at the metal of $112.0(2)^{\circ}$. The coordination is completed by a single tert-butoxide ligand to form a slightly distorted tetrahedral geometry. The complex is centrosymmetric (Figure 2; for ORTEP diagram see Figure S2 in the ESI) with the 
two vanadyl cations lying on opposite sides of the plane of the central phenyl ring in similar fashion to $\mathbf{1}$.

Synthesis and structure of $m-L^{2} H_{4}$ derived vanadyl complexes: Similar treatment of the meta ligand $\mathrm{L}^{2} \mathrm{H}_{4}$ with a slight excess of $\left[\mathrm{VO}(\mathrm{OnPr})_{3}\right]$ led to the formation of the complex $\left\{[\mathrm{VO}(\mathrm{OnPr})]_{2}\left(\mu-m-\mathrm{L}^{2}\right)\right\}(\mathrm{R}=n \mathrm{Pr}(3))$. The IR spectra contain a strong band at $c a 990 \mathrm{~cm}^{-1}$ assigned to the $v(\mathrm{~V}=\mathrm{O})$ mode. Unsurprisingly, the ${ }^{51} \mathrm{~V}$ NMR spectrum is very similar to that of $\mathbf{1}$ with a single peak at $\delta-432.5$ with $\omega_{\frac{1}{2}} 170 \mathrm{~Hz}\left(c f-433.3 \mathrm{ppm}, \omega_{\frac{1}{2} 2} 170 \mathrm{~Hz}\right.$ for 1$)$; see Table S5 for all ${ }^{51} \mathrm{~V}$ NMR spectroscopic data. Crystals of $\mathbf{3}$ suitable for an X-ray diffraction study were obtained on cooling of a THF/light petroleum solution to $-20{ }^{\circ} \mathrm{C}$. A tiny orange platelet was extracted from the solid product. This was examined at $100 \mathrm{~K}$ using synchrotron radiation (DLS beam-line I19, $\lambda=0.6889 \AA$ ). [14] The crystal was extremely weakly scattering and no significant diffraction was obvious beyond $c a .2 \theta=36^{\circ}$. It proved possible to solve the structure using direct methods and the chemical connectively is unequivocally established (Figure 3; for ORTEP diagram see Figure S3 in the ESI). No data beyond $36^{\circ}$ were used in the structure refinement.

The structure contains two independent units that are chemically identical. Each is formed of one half of a molecule of $\mathbf{L}^{2}$. The second half is generated by symmetry. Each symmetry unique fragment is based upon bidentate coordination of $\mathbf{L}^{2}$ to the vanadyl cation $(\mathrm{V}=\mathrm{O})^{2+}$. Coordination about the vanadyl is completed by tetrahydrofuran and $n$-propoxide to give trigonal bipyramidal geometry about the $\mathrm{V}$ center. There is some evidence for disordered solvent between these coordination complexes but we have not been able to resolve this. 


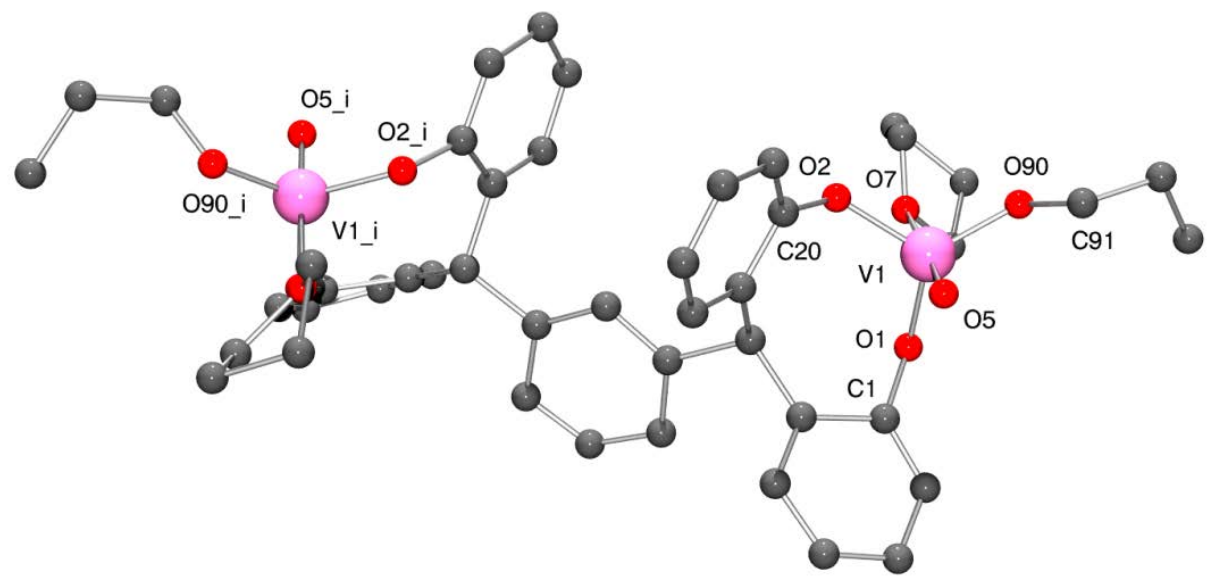

Figure 3: One of the symmetry unique complexes within 3 showing the meta arrangement in ligand $\mathbf{L}^{2}$. Tertiary butyl groups and hydrogen atoms have been omitted for clarity. Symmetry equivalent atoms are generated by the operator $i=1 / 2-x, y, 1 / 2-z$.

Synthesis and structure of oxo-imido complexes: The effective use of (imido)vanadium complexes as pre-catalysts for $\alpha$-olefin polymerization has been noted previously. [15] Given this, we have also explored possible routes to accessing imido-containing vanadium complexes of the tetra-phenol ligand set.

Treatment of the para ligand $\mathrm{L}^{1} \mathrm{H}_{4}$ with a slight excess of $\left[\mathrm{V}\left(\mathrm{Np}-\mathrm{R}^{1} \mathrm{C}_{6} \mathrm{H}_{4}(\mathrm{OtBu})_{3}\right]\left(\mathrm{R}^{1}=\mathrm{Me}, \mathrm{CF}_{3}\right)\right.$ led to the formation of the oxo-imido complexes $\left\{[\mathrm{VO}(t \mathrm{BuO})]\left[\mathrm{V}\left(\mathrm{N} p-\mathrm{R}^{1} \mathrm{C}_{6} \mathrm{H}_{4}\right)(t \mathrm{BuO})\right]\left(\mu-p-\mathrm{L}^{1}\right)\right\}$ $\left(\mathrm{R}^{1}=\mathrm{Me}, \mathbf{4} ; \mathrm{CF}_{3}, \mathbf{5}\right)$. Crystals of 4 and 5 suitable for an X-ray diffraction study were obtained on prolonged cooling of a saturated dichloromethane solution (to $-20{ }^{\circ} \mathrm{C}$ ). The molecular structures are shown in Figures 4 and 5 (for ORTEP diagrams see Figures S4 and S5 in the ESI), with selected bond lengths $(\AA)$ and angles $\left(^{\circ}\right)$ given in Table 2. For $\mathbf{4}$, each vanadium center adopts a pseudo-tetrahedral geometry, with bond angles in the range 106.7(2) - 112.1(2) ${ }^{\circ}$. The molecule is centro-symmetric. Each 8-membered metallocycle adopts the boat conformation, and the bite angle of the chelate at each end is $111.80(18)^{\circ}$. The tert-butoxide ligand is again somewhat bent 
[V1 $-\mathrm{O} 4-\mathrm{C} 40=144.5(4)^{\circ}$ ], whilst the organoimido group is near linear [V1 $-\mathrm{N} 1-\mathrm{C} 45=$ $\left.172.8(6)^{\circ}\right]$.

In the case of $\mathbf{5}$, the molecule also lies on a center of symmetry and so again half is unique. There is therefore disorder such that at V1 there is a 50/50 mixture of (i) a vanadyl and an unbound $\mathrm{CH}_{2} \mathrm{Cl}_{2}$ molecule and (ii) the $p$-arylimido group. We interpret this as being (i) at one end and (ii) at the other but that the arrangement is not regular throughout the crystal. As in 4, the organoimido group is near linear [V1 $-\mathrm{N} 1-\mathrm{C} 1=173.4(6){ }^{\circ}$ ], whereas the alkoxide is bent [V1 - O1 - C8 144.3(5) ${ }^{\circ}$ ]. The vanadyl group is involved in H-bonding to a solvent molecule $\left(\mathrm{CH}_{2} \mathrm{Cl}_{2}\right)$ with the geometrical parameters $\mathrm{H} 45 \mathrm{~A} \cdots \mathrm{O} 4=2.20 \AA$, angle at $\mathrm{H} 45=167^{\circ}, \mathrm{H} 45 \mathrm{~B} \cdots$ centroid of C30 - C35 = 2.85 , angle at $\mathrm{H} 45 \mathrm{~B}=136^{\circ}$. Molecules of 6 pack into chains but there are no significant interactions between molecules and chains.

Table 2. Selected bond lengths for $\mathbf{4} \cdot 2 \mathrm{CH}_{2} \mathrm{Cl}_{2}$ and $\mathbf{5} \cdot 2 \mathrm{CH}_{2} \mathrm{Cl}_{2}$

\begin{tabular}{ccc}
\hline Bond lengths $(\AA) /$ Angles $\left(^{\circ}\right)$ & $\mathbf{4} \cdot 2 \mathrm{CH}_{2} \mathrm{Cl}_{2}$ & $\mathbf{5} \cdot 2 \mathrm{CH}_{2} \mathrm{Cl}_{2}$ \\
\hline $\mathrm{V} 1-\mathrm{N} 1$ & $1.600(5)$ & $1.603(5)$ \\
$\mathrm{V} 1-\mathrm{O} 1$ & $1.735(4)$ & $1.734(5)$ \\
$\mathrm{V} 1-\mathrm{O} 2$ & $1.805(4)$ & $1.803(5)$ \\
$\mathrm{V} 1-\mathrm{O} 3$ & $1.797(4)$ & $1.802(4)$ \\
$\mathrm{V} 1-\mathrm{O} 1-\mathrm{C} 8$ & $144.4(4)$ & $144.3(5)$ \\
$\mathrm{V} 1-\mathrm{O} 2-\mathrm{C} 12$ & $125.7(4)$ & $126.0(4)$ \\
V1-O3-C30 & $127.5(4)$ & $125.2(4)$ \\
O1-V1-N1 & $112.1(2)$ & $111.8(3)$
\end{tabular}




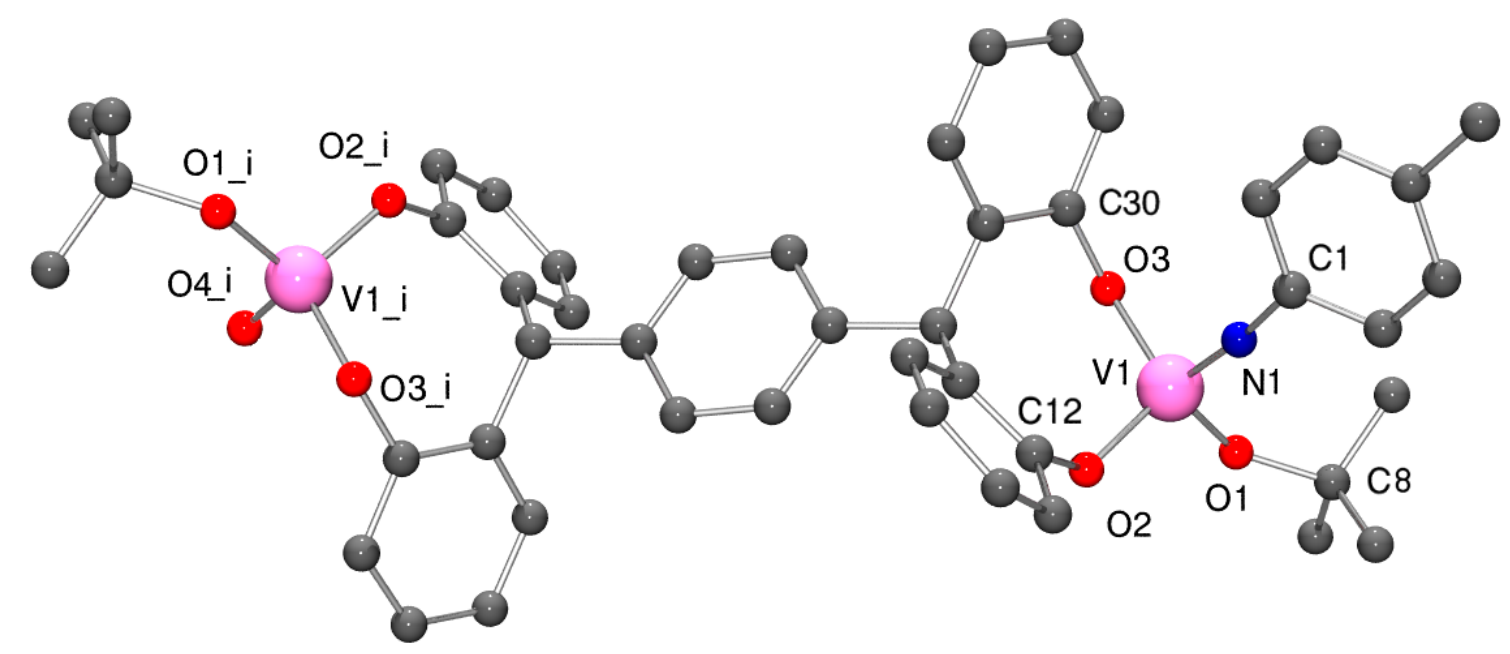

Figure 4. Molecular structure of complex $4 \cdot 2 \mathrm{CH}_{2} \mathrm{Cl}_{2}$, indicating the atom numbering scheme. tert-Butyl groups, hydrogen atoms, and unbound solvent molecules have been removed for clarity. Symmetry equivalent atoms are generated by the operator $i=1-x, 1-y, 2-z$.

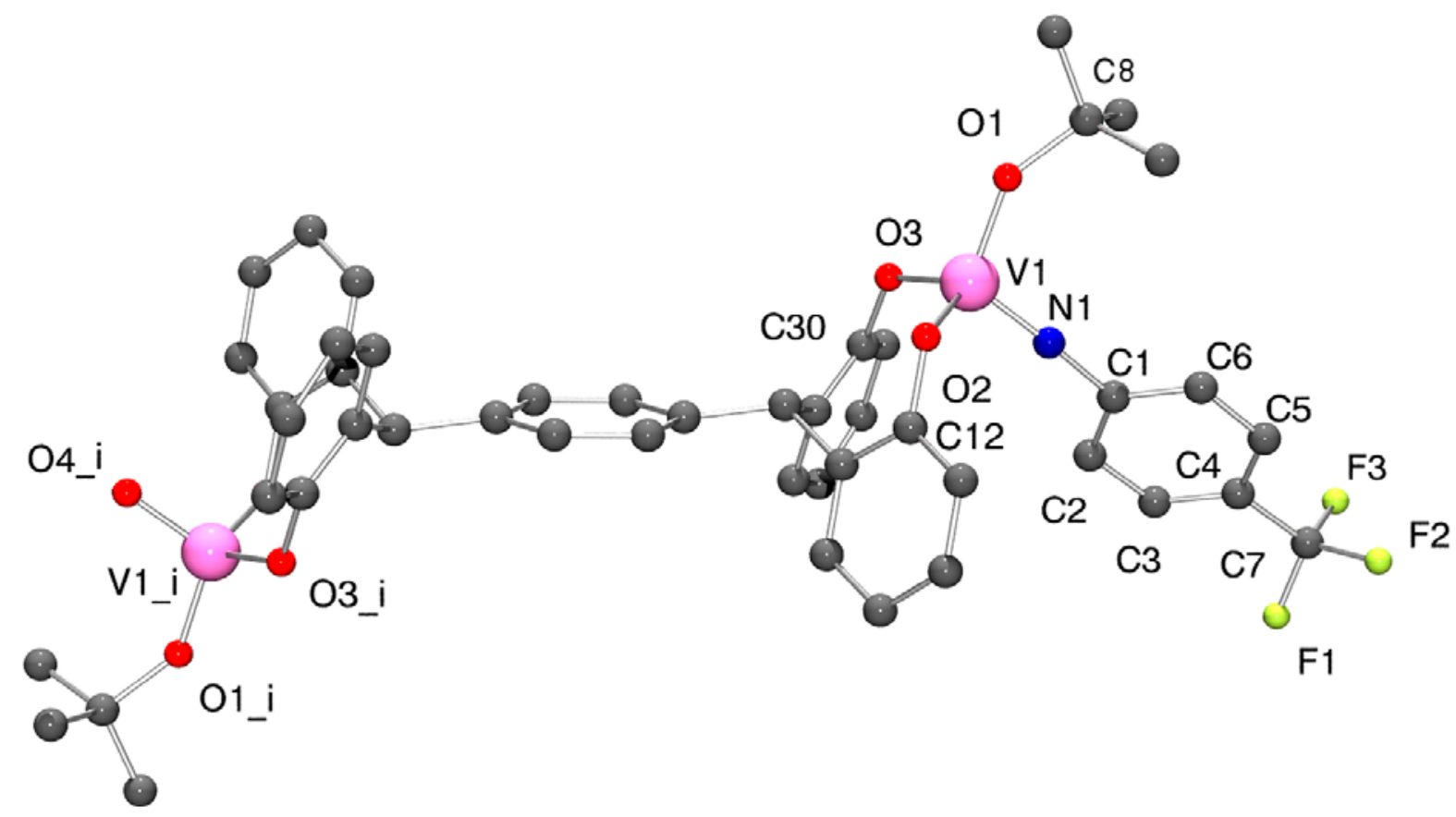

Figure 5. Molecular structure of complex $5 \cdot 2 \mathrm{CH}_{2} \mathrm{Cl}_{2}$, indicating the atom numbering scheme. tert-Butyl groups, hydrogen atoms, and unbound solvent molecules have been removed for 
clarity. Symmetry operation used to generate equivalent atoms: $\mathrm{i}=1-x, 1-y, 1-z$.

Synthesis and structure of bis-imido complexes: Given the sensitive nature of the tert-butoxides employed above, we turned out attention to use of the parent trichlorides, namely [ $\mathrm{V}(\mathrm{Np}$ $\left.\left.\mathrm{R}^{1} \mathrm{C}_{6} \mathrm{H}_{4}\right) \mathrm{Cl}_{3}\right] .[16]$

Interaction of $\left[\mathrm{V}\left(\mathrm{N} p-\mathrm{MeC}_{6} \mathrm{H}_{4}\right) \mathrm{Cl}_{3}\right]$ with the sodium salt $p-\mathrm{L}^{1} \mathrm{Na}_{4}$ afforded the complex $\{[\mathrm{V}(\mathrm{N} p$ $\left.\left.\left.\mathrm{MeC}_{6} \mathrm{H}_{4}\right)(\mathrm{THF}) \mathrm{Cl}\right]_{2}\left(\mu-p-\mathrm{L}^{1}\right)\right\}$ (6-4toluene) as a red/brown crystalline solid. The molecular structure of 6.4toluene is shown in Figure 6 (for ORTEP diagram see Figure S6 in the ESI), with selected bond lengths and angles given in the caption. The geometry at vanadium is best described as trigonal bipyramidal with the imido and THF groups occupying axial positions [N(1) $-\mathrm{V}(1)-\mathrm{O}(3) 175.11(16)^{\circ}{ }^{\circ}$. Distortions are in the range $110.17(12)-123.9(2)^{\circ}$, with the largest deviation associated with the angle subtended at the metal by the phenolic oxygen centers; the metallocycle adopts a boat conformation. The imido ligand has the geometrical parameters associated with a linear imido function [V(1) - N(1) 1.656(4) $\AA$; V(1) - N(1) - C(50) 170.4(3) ${ }^{\circ}$ ]. 


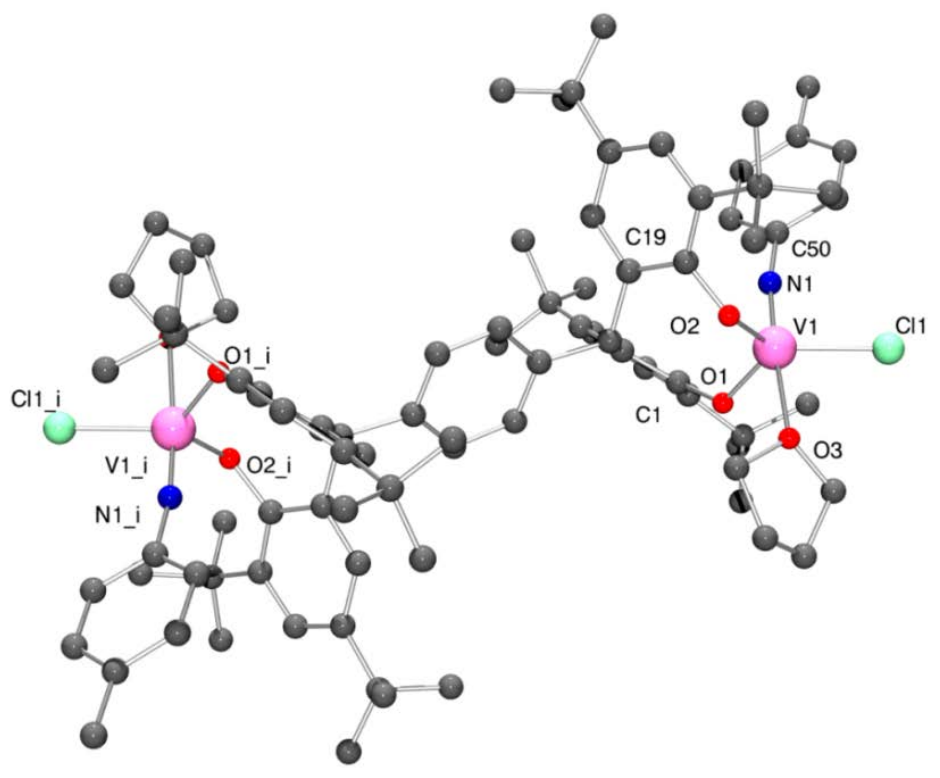

Figure 6. Molecular structure of complex 6.4toluene, indicating the atom numbering scheme. Hydrogen atoms have been removed for clarity. Selected bond lengths $(\AA)$ and angles $\left(^{\circ}\right)$ : V(1)N(1) 1.656(4), V1-O1 1.819(3), V1-O2 1.817(3), V1-O3 2.189(3), V1-Cl1 2.2814(14); O1V1-N1 98.84(15), O1-V1-O2 110.17(12), Cl1-V1-N1 92.89(12), V1-O1-C1 126.9(2), V1O2-C19 120.6(3), V1-N1-C50 170.4(3). Symmetry operation used to generate equivalent atoms: $\mathrm{i}=-x, 1-y,-z$.

Similar use of $\left[\mathrm{V}\left(\mathrm{Np}-\mathrm{CF}_{3} \mathrm{C}_{6} \mathrm{H}_{4}\right) \mathrm{Cl}_{3}\right]$ with $\mathrm{L}^{1} \mathrm{H}_{4}$ led to the isolation of $\{[\mathrm{V}(\mathrm{Np}$ $\left.\left.\left.\mathrm{CF}_{3} \mathrm{C}_{6} \mathrm{H}_{4}\right)(\mathrm{THF}) \mathrm{Cl}\right]_{2}\left(\mu-p-\mathrm{L}^{1}\right)\right\}$ (7) in moderate yield (ca. $47 \%$ ). Crystals suitable for X-ray diffraction were obtained from a saturated solution of acetonitrile at ambient temperature. Although the data are not of the best quality, the connectivity is clear and the molecular structure is shown in Figure 7 (for ORTEP diagram see Figure S7 in the ESI). In the ${ }^{51} \mathrm{~V}$ NMR spectra of 4 and 5 there are two peaks (see table S5); imido peaks are usually found downfield of their 
vanadyl counterparts. [16]

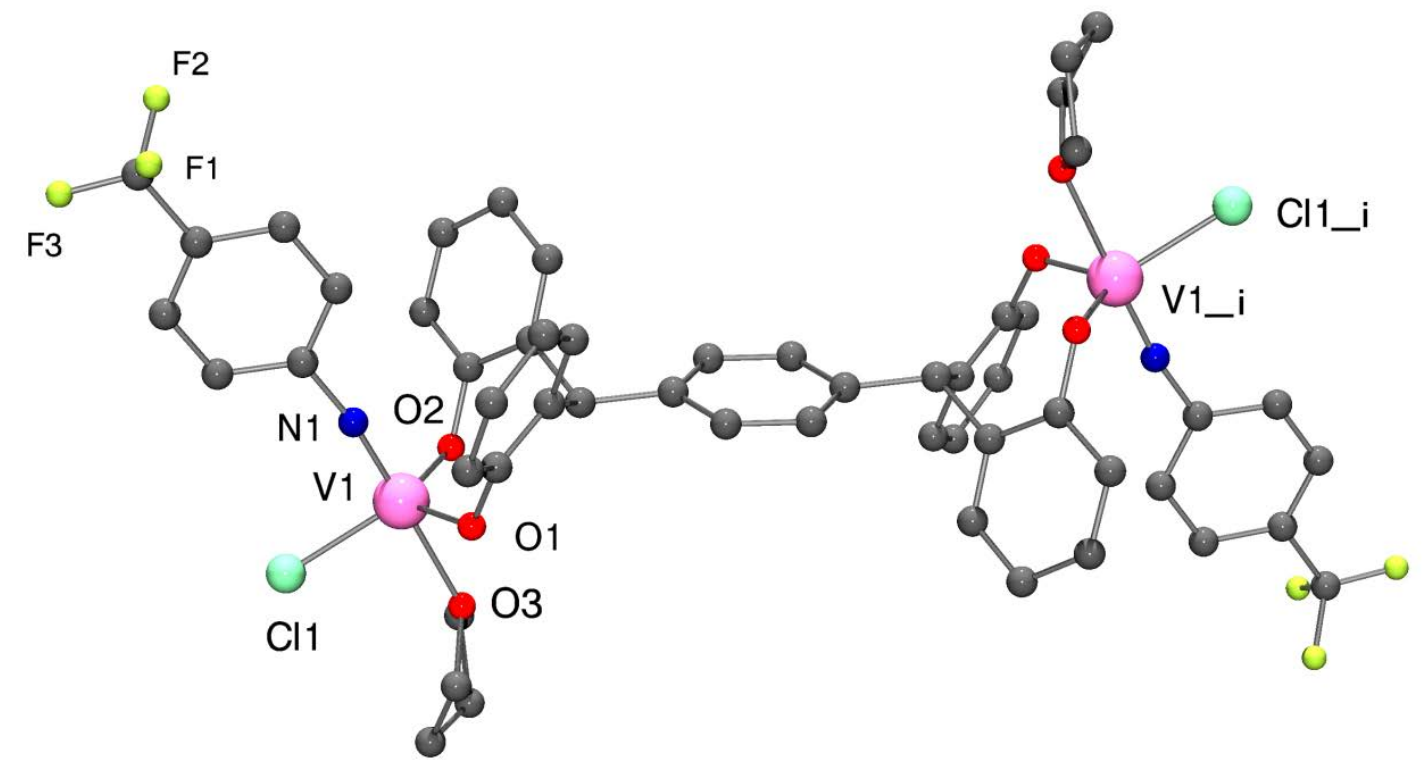

Figure 7. Molecular structure of complex 7, indicating the atom numbering scheme. Hydrogen atoms and tert-butyl groups have been removed for clarity. Selected bond lengths ( $\AA$ ) and angles $\left(^{\circ}\right)$ V(1)-N(1) 1.666(4), V1-O1 1.808(3), V1-O2 1.819(3), V1-O3 2.210(3), V1-Cl1 2.2625(14); O1-V1-N1 99.05(18), O1-V1-O2 112.47(14), Cl1-V1-N1 95.29(14), V1-O1-C1 122.7(3), V1-O2-C19 121.5(3), V1-N1-C34 172.0(4).

Under the conditions employed herein, on several occasions, small amounts of spiro-type compounds containing the motif I (see Figure 8) were isolated. In particular, the spiro compound with $\mathrm{X}=t \mathrm{Bu}$ was isolated from the reaction employing $\left[\mathrm{V}\left(\mathrm{NC}_{6} \mathrm{H}_{4} \mathrm{CF}_{3}-p\right) \mathrm{Cl}_{3}\right]$, whilst that with $\mathrm{X}$ $=\mathrm{Cl}$ resulted from attempts to form a vanadyl chloride complex of $p-\mathrm{L}^{1} \mathrm{H}_{4}$ using $\left[\mathrm{VOCl}_{3}\right]$. The crystal structures of both spiro compounds are presented in the ESI (see Figures S8 and S9 and Tables S1-4). A search of the Cambridge Crystallographic Database (CSD) for motifs related to I revealed 7 hits in calixarene type systems. $[17,18]$ 


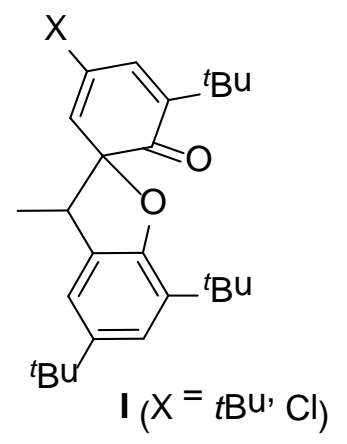

Figure 8. Spiro motif $\mathbf{I}$.

Use of $\mathbf{L}^{3} \mathbf{H}_{2}$ : For comparative studies, we have also treated the potentially bidentate ligand $\mathbf{L}^{3} \mathbf{H}_{2}$ with $\left[\mathrm{VO}(\mathrm{OnPr})_{3}\right]$, which led to the formation of compound $\mathbf{8}$. In the IR spectrum, a strong band at $989 \mathrm{~cm}^{-1}$ is assigned to the vanadyl group. Compound $\mathbf{8}$ was crystallized from light petroleum to give red needles which were suitable for single crystal X-ray diffraction. The crystal structure revealed that compound $\mathbf{8}$ forms a dimeric structure in the solid state (see Figure 9; for ORTEP diagram see Figure S10 in the ESI). The vanadium oxytri-n-propoxide loses two equivalents of propanol on binding to the bidentate ligand. The dimer is centrosymmetric and contains two vanadyl moieties in a trans arrangement that are bridged by the two remaining $n$-propoxide ligands. Each vanadium metal center is in trigonal bipyramidal geometry; the bidentate ligand and one of the $n$-propoxide ligands occupying the equatorial position, the vanadyl oxygen and second $n$-propoxide occupies the axial position. The di-phenolate ligand's third phenol ring is rotated away with the methine hydrogen directed toward the vanadium center. Unlike for complexes $\mathbf{1}$ and $\mathbf{3}$ which contain terminal $n$-propoxide ligands, the presence of the bridging $n$ propoxides in $\mathbf{8}$ together with the bulky chelate ligand appears to prevent ligation by THF. As in the tetra-phenolate systems above, the 8-membered metallocycle in $\mathbf{8}$ adopts a boat conformation, for which the bite angle subtended at vanadium is $113.14(7){ }^{\circ}$. A search of the CSD for use of di- 
phenols with an aryl group bound at the bridging carbon afforded 114 hits for metal complexes, however most of these were either based on tripodal ligands or where the motif of interest formed part of a more exotic ligating species. Indeed, there was only one example of the previous use of the parent $\mathbf{L}^{3} \mathbf{H}_{2}$, which was a report of its utilization in titanium chemistry. [17, 19]

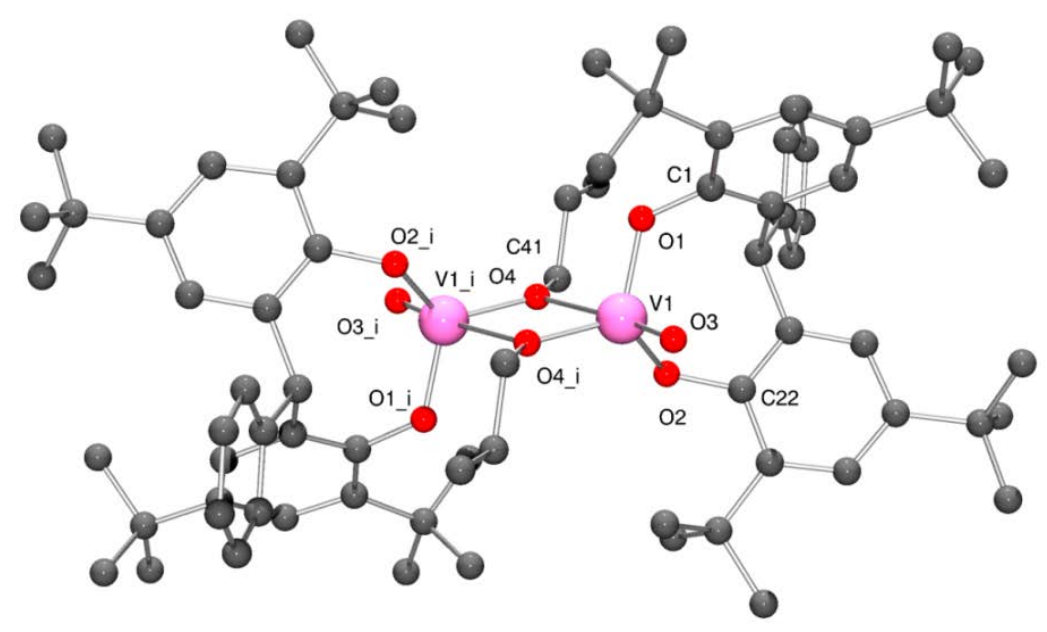

Figure 9. Representation of the molecular structure of complex 8, indicating the atom numbering scheme. For clarity, hydrogen atoms have been removed. One of the symmetry independent $t$ butyl groups is disordered over two positions. Selected bond lengths $(\AA)$ and angles $\left({ }^{\circ}\right)$ : O1-V1 1.8117(15), O2-V1 1.8165(16), O3-V1 1.5869(15), O4-V1 1.8348(15), O4 -V1 2.2917(14), V1-O4 ${ }^{i}$ 1.8348(15), V1 ${ }^{i}-\mathrm{O} 4-\mathrm{V} 1$ 108.23(6), O3-V1-O1 100.19(7), O3-V1-O2 100.58(8), O1V1-O2 113.14(7), O3-V1-O4 100.35(7), O1-V1-O4 115.74(7), O2-V1-O4 $4^{i} 121.56(7)$, O3V1-O4 172.06(7), O1-V1-O4 84.55(6), O2-V1-O4 83.19(6), O4-V1-O4 71.77(6). Symmetry equivalent atoms are generated by the operator $i=1-x, 1-y, 2-z$. 


\section{Ethylene Polymerization Screening}

Compounds $\mathbf{1}$ - 3, 5 - 8 and $\left[\mathrm{VO}(\mathrm{OEt}) \mathrm{Cl}_{2}\right]$, were screened for the polymerization of ethylene. Each catalyst has been screened for polymerization using different co-catalysts (DMAC, Dimethylaluminium chloride; DEAC, diethylaluminium chloride; EADC, ethylaluminium dichloride; EASC, ethylaluminium sesquichloride) and with addition of ETA (ethyltrichloroacetate). From the co-catalyst screening (Tables 3, S6, S7 and Figures S11-S46 in the ESI; for use of $\mathrm{Me}_{3} \mathrm{Al}, \mathrm{Et}_{3} \mathrm{Al}$ and DMAO (dried MAO - see general experimental), see Tables S8 and S9, ESI), the addition of ETA to the catalytic system is beneficial; the activity of the runs including an addition of ETA was always higher than with no addition (Table 3). [20] In all cases, the addition of larger equivalence of ETA and co-catalyst lead to improved activity. Use of different chloro-aluminium alkyls indicated, for compound 1, that DEAC was the cocatalyst of choice giving the highest activity and lowest molecular weight distribution (Table 3, run 4); compound 3 gave similar activities for each co-catalyst (ie no advantage of meta versus para ligation), whereas surprisingly, given the similarities with $\mathbf{3}$, compound $\mathbf{8}$ gave much higher activities when using the ethyl derived aluminium chloride co-catalysts (see Table 3, runs 20 27). For compounds 1 and 3, EADC and EASC gave lower activities than DEAC and lower molecular weights than DMAC. The highest molecular weight polyethylene was obtained using DMAC as co-catalyst; however the PDI values were high for each pre-catalyst employed suggesting multiple active species.

Table 3. Selected results for the effect of co-catalyst and ETA on compounds $\mathbf{1}-\mathbf{3 , 5} \mathbf{8}$ and [VO(OEt)Cl $\mathbf{C l}_{2}{ }^{a}$

\begin{tabular}{|c|c|c|c|c|c|c|c|c|c|c|}
\hline Run & Pre-Cat & Co-Cat & $\mathbf{A l} / \mathbf{V}$ & $\begin{array}{r}\text { ETA/ } \\
V\end{array}$ & $\mathbf{T}^{c}$ & Yield $^{b}$ & Activity $^{d}$ & $M_{\mathrm{w}}$ & $M_{\mathrm{n}}$ & PDI \\
\hline 1 & 1 & DMAC & 20000 & & 30 & 0.128 & 12,800 & $2,261,718$ & 547,734 & 4.1 \\
\hline 2 & & & 20000 & 20000 & 30 & 0.534 & 53,400 & 974,413 & 116,671 & 8.4 \\
\hline
\end{tabular}




\begin{tabular}{|c|c|c|c|c|c|c|c|c|c|c|}
\hline 3 & & DEAC & 20000 & & 30 & 0.009 & 900 & 455,970 & 88,930 & 5.1 \\
\hline 4 & & & 20000 & 20000 & $10^{\mathrm{e}}$ & 0.811 & 243,400 & 73,074 & 25,671 & 2.9 \\
\hline 5 & & EADC & 20000 & & 30 & 0.05 & 5,000 & 228,678 & 94,326 & 2.4 \\
\hline 6 & & & 20000 & 20000 & 30 & 0.338 & 33,800 & 749,498 & 205,539 & 3.7 \\
\hline 7 & & EASC & 20000 & & 30 & 0.058 & 5,800 & 943,144 & 353,483 & 2.7 \\
\hline 8 & & & 20000 & 20000 & 30 & 0.358 & 35,800 & 666,983 & 160,727 & 4.2 \\
\hline 9 & 2 & DMAC & 20000 & 20000 & 30 & 0.306 & 122,200 & $1,180,000$ & 241,000 & 4.9 \\
\hline 10 & & DEAC & 20000 & 20000 & 30 & 0.231 & 92,300 & $1,040,000$ & 103,000 & 10.0 \\
\hline 11 & 3 & DMAC & 20000 & & 30 & 0.112 & 11,200 & $3,290,580$ & $1,349,253$ & 2.44 \\
\hline 12 & & & 20000 & 20000 & 30 & 0.45 & 45,000 & 865,647 & 81,817 & 10.6 \\
\hline 13 & & DEAC & 20000 & 20000 & 30 & 0.494 & 49,400 & 267,660 & 45,443 & 5.9 \\
\hline 14 & & EADC & 20000 & & 30 & 0.01 & 1000 & 196,554 & 57,342 & 3.4 \\
\hline 15 & & & 20000 & 20000 & 30 & 0.472 & 47,200 & 749,897 & 70,411 & 10.6 \\
\hline 16 & & EASC & 20000 & & 30 & 0.034 & 3,400 & 967,997 & 315,747 & 3.1 \\
\hline 17 & & & 20000 & 20000 & 30 & 0.438 & 43,800 & 273,709 & 27,818 & 9.8 \\
\hline 18 & 5 & DMAC & 20000 & 20000 & 30 & 0.256 & 102,200 & 814,000 & 123,000 & 6.6 \\
\hline 19 & & DEAC & 20000 & 20000 & 30 & 0.237 & 94,700 & 933,000 & 88,800 & 10.5 \\
\hline 20 & 8 & DMAC & 20000 & & 30 & 0.341 & 34,100 & $1,683,732$ & 57,625 & 29.2 \\
\hline 21 & & & 20000 & 20000 & 30 & 0.423 & 42,300 & $1,067,563$ & 120,753 & 8.84 \\
\hline 22 & & DEAC & 20000 & & 30 & 0.039 & 3,900 & 333,763 & 104,963 & 3.2 \\
\hline 23 & & & 20000 & 20000 & $15^{e}$ & 0.527 & 105,400 & 110,765 & 26,097 & 4.2 \\
\hline 24 & & EADC & 20000 & & 30 & 0.0107 & 1,100 & 181,151 & 68,551 & 2.6 \\
\hline 25 & & & 20000 & 20000 & $23^{e}$ & 0.538 & 70,200 & 547,756 & 135,546 & 4.0 \\
\hline 26 & & EASC & 20000 & & 30 & 0.0305 & 3,100 & 874,365 & 191,854 & 4.6 \\
\hline 27 & & & 20000 & 20000 & $22^{e}$ & 0.4951 & 67,500 & 216,581 & 29,627 & 7.3 \\
\hline 28 & $\begin{array}{l}{[\mathrm{VO}(\mathrm{O}} \\
\left.\mathrm{Et}) \mathrm{Cl}_{2}\right]\end{array}$ & DMAC & 20000 & & 30 & 0.106 & 21,200 & $2,114,696$ & 740,175 & 2.9 \\
\hline 29 & & & 20000 & 20000 & 30 & 0.429 & 85,800 & 1,787,338 & 385,401 & 4.6 \\
\hline 30 & & DEAC & 20000 & 20000 & 30 & 0.343 & 68,600 & 139,330 & 48,676 & 2.9 \\
\hline 31 & & EADC & 20000 & 20000 & 30 & 0.375 & 37,500 & 711,232 & 187,694 & 3.8 \\
\hline
\end{tabular}


${ }^{a}$ Conditions: $50{ }^{\circ} \mathrm{C}, 5 \mathrm{~mL}$ toluene, $0.01 \mu \mathrm{mol} \mathrm{V}, 0.8 \mathrm{MPa}$ ethylene, reaction quenched with isobutyl alcohol; ${ }^{b}$ grams, ${ }^{\mathrm{c}}$ minutes, ${ }^{\mathrm{d}}(\mathrm{g} /(\mathrm{mmol} . \mathrm{h}))$, ${ }^{\mathrm{e}}$ polymerization was stopped due to consumption of stock ethylene. See ESI for full screening results - Table S5.

Comparison of the observed catalytic activities and molecular weights $\left(M_{\mathrm{w}}\right)$ for the dinuclear vanadyl complexes bridged with a tetra-phenolate ligand versus the $n$-propoxide bridged vanadyl complex 8 revealed that the use of different co-catalysts as well as the presence or absence of ETA played a significant role. For example, in the presence of ETA, all tetra-phenolate bridged systems were more active than the $n$-propoxide bridged vanadyl complex $\mathbf{8}$, however the polyethylene produced via 8/ETA tended to be of higher molecular weight $\left(M_{\mathrm{w}}\right)$. In the absence of ETA, 8/DMAC exhibited higher activities than did the tetra-phenolate bridged systems, although in this case, the polyethylene was of higher molecular weight for the tetra-phenolate bridged systems. The use of DEAC as co-catalyst generally afforded the same trends as DMAC for $\mathbf{1}$, whereas for $\mathbf{2}, \mathbf{3}$ and $\mathbf{5}$ with ETA, the activities were less than observed for $\mathbf{8} / \mathrm{ETA}$; molecular weights were higher for the tetra-phenolate bridged systems. With EADC or EASC, activities in the presence of ETA were higher for 8, but molecular weights for the PE obtained were higher for the tetra-phenolate bridged systems. In the absence of ETA, activities for $\mathbf{1}$ were higher than for $\mathbf{8}$, whilst for $\mathbf{3}$ they were about the same as those observed for $\mathbf{8}$; molecular weights for the PE obtained were higher for the tetra-phenolate bridged systems.

Using the conditions established in Table 3 (20,000 equivalence DEAC or DMAC, 20,000 equivalence ETA) compounds $\mathbf{1}$ - 3, 5 - 8 and the reference compound $\left[\mathrm{VO}(\mathrm{OEt}) \mathrm{Cl}_{2}\right]$ were screened over a series of temperatures (Tables 4 and S7 and Figures S27-S42 in the ESI). When 
DMAC was used as co-catalyst, the vanadyl-containing pre-catalysts $\mathbf{1}-\mathbf{3 ,} 5$ and [VO(OEt)Cl ${ }_{2}$ ] showed optimal activity at $50{ }^{\circ} \mathrm{C}$, whereas the $n$-propoxide bridged pre-catalyst 8 is thermally more stable and gave highest activity at $80{ }^{\circ} \mathrm{C}$; each compound except for compound $\mathbf{8}$ showed lower PDI values at $80{ }^{\circ} \mathrm{C}$. In the runs where DEAC was employed as co-catalyst again $50{ }^{\circ} \mathrm{C}$ was the temperature of choice, except for compound $\mathbf{1}$ where a temperature of $80{ }^{\circ} \mathrm{C}$ showed increased activity.

For the non-vanadyl (imido) pre-catalysts 6 and 7, observed activities were higher when employing DEAC versus DMAC at $50{ }^{\circ} \mathrm{C}$, with activities as high as 236,000 g/(mmol.hr) (29.5 $\mathrm{Kg} \mathrm{PE} / \mathrm{mmolV}$.h.bar) recorded; pre-catalyst 6 bearing the $p$-tolyl groups gave higher activities than 7 bearing the $p-\mathrm{CF}_{3}$ group at $50{ }^{\circ} \mathrm{C}$ for both DMAC and DEAC. At $80{ }^{\circ} \mathrm{C}$, the activities fell off dramatically when using either DMAC or DEAC, with no products isolated at the higher temperatures of 100 and $144{ }^{\circ} \mathrm{C}$. Indeed, the fall-off in the observed activity was far steeper for these imido systems than was observed for any of the vanadyl systems. The molecular weights of the polymers isolated at 50 and $80{ }^{\circ} \mathrm{C}$ were higher when obtained in the presence of DMAC, and in the case of $\mathbf{6}$ at $50{ }^{\circ} \mathrm{C}$, were larger than any of the molecular weights $\left(M_{\mathrm{w}}\right)$ observed herein when using the vanadyl complexes. However, the molecular weights $\left(M_{\mathrm{w}}\right)$ of the PE obtained using 6 or 7 in combination with DEAC/ETA were much lower than those observed when employing the vanadyl complexes under similar conditions.

Table 4. Effect of temperature on compounds $\mathbf{1}$ - 3, 5 - 8 and $\left[\mathrm{VO}(\mathrm{OEt}) \mathrm{Cl}_{2}\right]^{a}$

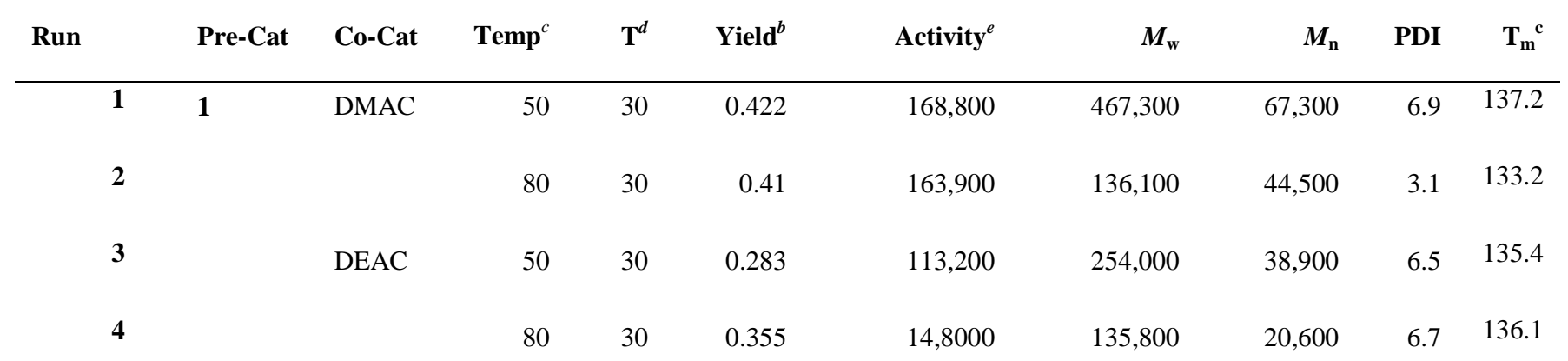




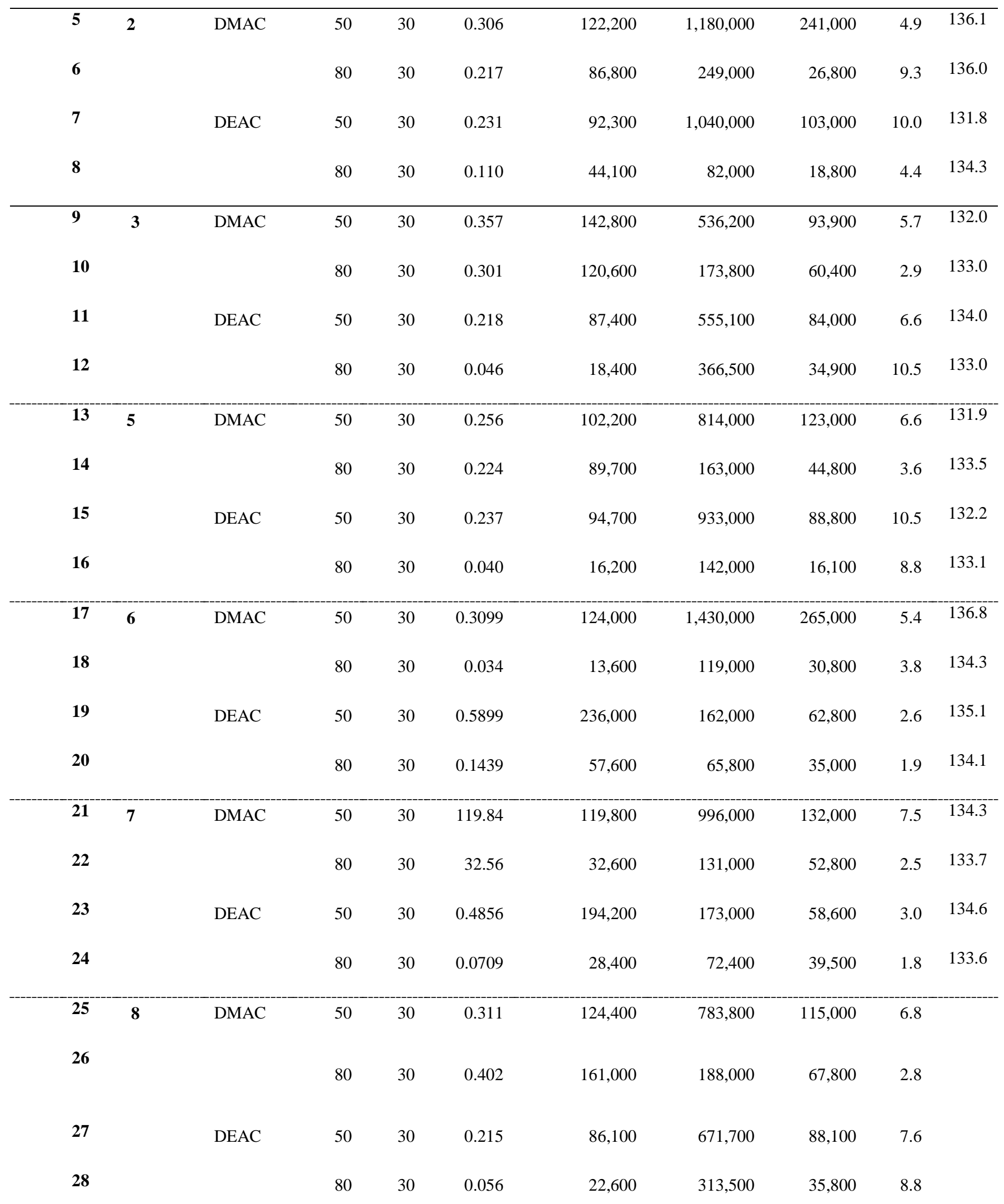




\begin{tabular}{|c|c|c|c|c|c|c|c|c|c|c|}
\hline 29 & $\begin{array}{l}\text { IVO(OE } \\
\left.\text { t)Cl } \mathrm{Cl}_{2}\right]\end{array}$ & DMAC & 50 & 30 & 0.374 & 74,700 & 945,800 & 168,700 & 5.6 & 134.7 \\
\hline 30 & & & 80 & 30 & 0.354 & 70,800 & 137,600 & 45,700 & 3.0 & 133.3 \\
\hline 31 & & DEAC & 50 & 30 & 0.483 & 96,700 & 316,500 & 56,800 & 5.6 & 134.4 \\
\hline 32 & & & 80 & 30 & 0.237 & 47,400 & 208,700 & 27,200 & 7.7 & 134.0 \\
\hline
\end{tabular}

${ }^{a}$ Conditions: $5 \mathrm{~mL}$ toluene, $0.005 \mu \mathrm{mol}$ V, 0.8 MPa ethylene, 20,000 equivalents Co-catalyst, 20,000 equivalents ETA, reaction quenched with iso-butyl alcohol; ${ }^{b}$ grams, ${ }^{\mathrm{c}}{ }^{\circ} \mathrm{C},{ }^{\mathrm{d}}$ minutes, ${ }^{\mathrm{e}}$ (g/(mmol.h)).

The polyethylene formed is highly linear, with melting points in the range $130.2-137.2^{\circ} \mathrm{C}$, and no branching could be assigned from the ${ }^{13} \mathrm{C}$ NMR spectra (for example, see Figure S43 in the ESI for catalyst system using 2/Et $\mathrm{AlCl}_{2}$ - run 31, Table S6). [21]

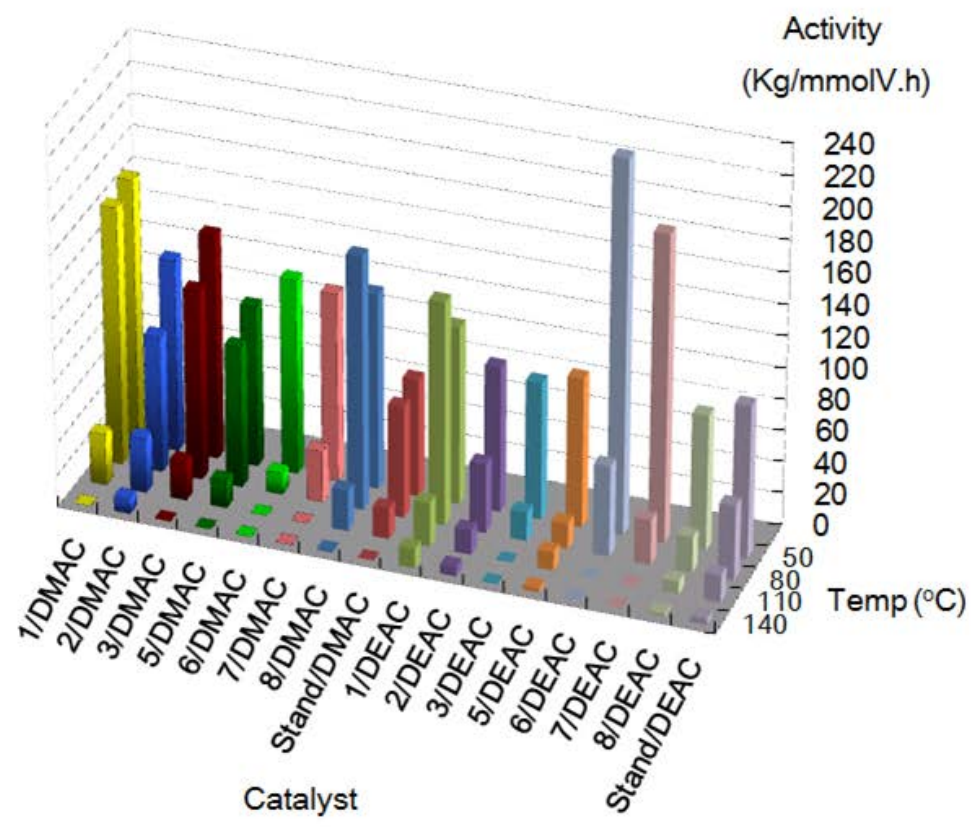

Figure 10. Activity $\left(\mathrm{x} 10^{3} \mathrm{~g}(\mathrm{mmol}(\mathrm{V}) \mathrm{h})^{-1}\right)$ in ethylene polymerization at $50-140{ }^{\circ} \mathrm{C}$ by $\left[\mathrm{VO}(\mathrm{OEt}) \mathrm{Cl}_{2}\right], 1$ $-3,5$ - 8. 
Screening using $\mathrm{Me}_{3} \mathrm{Al}, \mathrm{Et}_{3} \mathrm{Al}$ or DMAO as co-catalysts in the presence of ETA proved unsuccessful (see tables S8 and S9, ESI), i.e. such systems were inactive under the conditions employed herein. We note that improved activities in vanadium-based systems in the presence of chloroaluminium co-catalysts have previously been associated with the presence of $\mathrm{V}$-Cl-Al type motifs present in the active species, [2b] and with the nature of the ion-pair formed. Smaller cocatalysts such as DMAC or DEAC versus MAO are capable of equilibria involving chlorobridged species and discrete ions. [22]

\section{Ethylene/Propylene Co- Polymerization Screening}

The co-polymerization of propylene and ethylene using compounds $\mathbf{1}$ - $\mathbf{3 , 5}$ - $\mathbf{8}$ and [ $\left.\mathrm{VO}(\mathrm{OEt}) \mathrm{Cl}_{2}\right]$ at $50{ }^{\circ} \mathrm{C}$ revealed (see Table 5 and Figures S44-S46 in the ESI) that DMAC, in combination with the vanadyl-containing pre-catalysts, was a more efficient co-catalyst than DEAC, achieving an activity greater than $100,000 \mathrm{~g} / \mathrm{mmol}$.h for pre-catalysts $\mathbf{1}, \mathbf{3}, \mathbf{8}$ and $\left[\mathrm{VO}(\mathrm{OEt}) \mathrm{Cl}_{2}\right]$. As for the homo-polymerization of ethylene, there was no advantage observed for the co-polymerization results herein when using a meta ligand framework over para ligation ( $1 \mathrm{v} \mathbf{3})$, despite the increased possibility of the former to bring the metals into closer proximity.

For the non-vanadyl systems 6 and 7, the activity observed was higher when using DEAC as cocatalyst, with the system employing pre-catalyst 6 achieving an activity of the order of 111,400 $\mathrm{g} / \mathrm{mmol}$.h. In all cases, the molecular weight $\left(M_{\mathrm{w}}\right)$ of the co-polymer produced was much higher when DMAC was employed as co-catalyst. In each run, the PDI values were typically in the range 1.8 - 2.8 (the exception was run 8). When using DMAC, the propylene incorporation for the vanadyl-containing systems was between 7.5 - $8.6 \%$ (7.2 - $8.5 \%$ for DEAC), whereas for 
the imido-containing systems, the incorporation was somewhat lower at $3.8-4.7 \%$ (DMAC) and $4.0-7.4 \%$ (DEAC). For the $n$-propoxide complex 8 , propylene incorporation was similar to the other vanadyl complexes [8.2 \% DMAC and $7.7 \%$ DEAC], whilst the C3 incorporation for the standard catalyst [VO(OEt)Cl $\mathrm{Cl}_{2}$ ] was slightly higher at $10.0 \%$ (DMAC) and $9.1 \%$ (DEAC).

Table 5. Ethylene/propylene co-polymerizations using compounds $\mathbf{1}$ - 3, 5 - 8 and $\left[\mathrm{VO}(\mathrm{OEt}) \mathrm{Cl}_{2}\right]^{a}{ }^{a}$

\begin{tabular}{|c|c|c|c|c|c|c|c|c|c|}
\hline Run & Pre-Cat & Co-Cat & Yield $^{b}$ & Activity $^{c}$ & $\% \mathrm{C3}^{d}$ & $M_{\mathrm{w}}$ & $M_{\mathrm{n}}$ & PDI & $\mathbf{T}_{\mathbf{m}}{ }^{\mathbf{e}}$ \\
\hline 1 & 1 & DMAC & 0.361 & 144,400 & 8.5 & 325,200 & 133,600 & 2.4 & 90.4 \\
\hline 2 & & DEAC & 0.203 & 81,000 & 8.3 & 88,800 & 46,400 & 1.9 & 93.4 \\
\hline 3 & 2 & DMAC & 0.145 & 57,880 & 8.6 & 217,100 & 100,500 & 2.2 & 86.6 \\
\hline 4 & & DEAC & 0.084 & 33,480 & 7.2 & 78,000 & 40,300 & 1.9 & 91.6 \\
\hline 5 & 3 & DMAC & 0.338 & 135,100 & 8.2 & 291,100 & 123,100 & 2.4 & 90.9 \\
\hline 6 & & DEAC & 0.116 & 46,400 & 7.6 & 98,300 & 43,200 & 2.3 & 95.0 \\
\hline 7 & 5 & DMAC & 0.214 & 85,560 & 7.5 & 241,200 & 103,800 & 2.3 & 89.1 \\
\hline 8 & & DEAC & 0.171 & 68,240 & 8.5 & 87,200 & 42,800 & 8.5 & 89.9 \\
\hline 9 & 6 & DMAC & 0.082 & 32,960 & 4.7 & 301,900 & 123,900 & 2.4 & 89.6 \\
\hline 10 & & DEAC & 0.278 & 111,360 & 7.4 & 108,000 & 53,700 & 2.0 & 88.2 \\
\hline 11 & 7 & DMAC & 0.099 & 39,440 & 3.8 & 289,500 & 117,800 & 2.5 & 86.8 \\
\hline 12 & & DEAC & 0.199 & 79,760 & 4.0 & 102,400 & 53,800 & 1.9 & 84.5 \\
\hline 13 & 8 & DMAC & 0.274 & 109,600 & 8.2 & 311,300 & 136,900 & 2.3 & 90.9 \\
\hline 14 & & DEAC & 0.189 & 75,600 & 7.7 & 99,300 & 53,000 & 1.9 & 93.6 \\
\hline 15 & $\begin{array}{l}\text { [VO(OEt)Cl } \\
2]\end{array}$ & DMAC & 0.391 & 156,200 & 10.0 & 241,100 & 86,600 & 2.8 & 88.9 \\
\hline 16 & & DEAC & 0.191 & 76,400 & 9.1 & 75,700 & 42,700 & 1.8 & 90.2 \\
\hline
\end{tabular}

\footnotetext{
${ }^{a}$ Conditions: $5 \mathrm{~mL}$ toluene, 30 minutes, $50{ }^{\circ} \mathrm{C}, 0.005 \mu \mathrm{mol} \mathrm{V}, 0.4 \mathrm{MPa}$ ethylene, $0.4 \mathrm{MPa}$ propylene, 20,000 equivalents co-catalyst, 20,000 equivalents ETA, reaction quenched with isobutyl alcohol; ${ }^{\text {grams, }}$ '(g/(mmol.h)), ${ }^{\mathrm{d}}$ Mol\% determined by IR. ${ }^{\mathrm{e}}{ }^{\circ} \mathrm{C}$.
} 
Whilst the catalytic activities of the systems described herein (see Figure 15) are amongst the highest yet reported for ethylene/propylene co-polymerization for vanadium-based systems, the degree of propylene incorporation [3.8 - $8.6 \mathrm{~mol} \%]$ is far lower than other reported systems; typically other systems incorporate between 15 - 40 mol\% C3. [4b-d, 11]

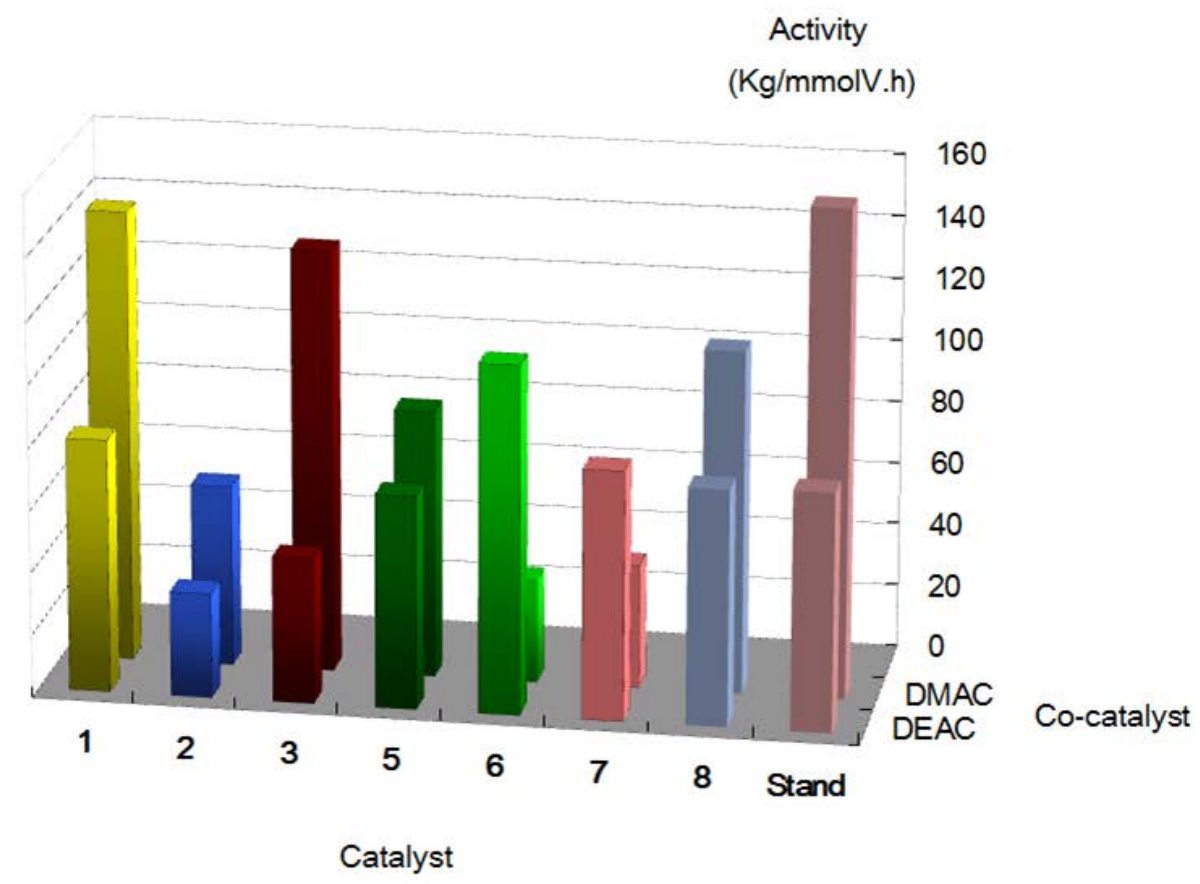

Figure 11. Activity (x $10^{3} \mathrm{~g}(\mathrm{mmol}(\mathrm{V}) \mathrm{h})^{-1}$ ) in ethylene/propylene co-polymerization at $50{ }^{\circ} \mathrm{C}$ by $\left[\mathrm{VO}(\mathrm{OEt}) \mathrm{Cl}_{2}\right], \mathbf{1}-\mathbf{3}$ and $\mathbf{5}-\mathbf{8}$ in the presence of DMAC or DEAC as co-catalyst.

In conclusion, the para or meta-tetra-phenols $p-\mathrm{L}^{1} \mathrm{H}_{4}$ or $m$ - $\mathrm{L}^{2} \mathrm{H}_{4}$ on reaction with $\left[\mathrm{V}(\mathrm{X})(\mathrm{OR})_{3}\right](\mathrm{X}=$ oxo or imido) allow access to two new families of bimetallic complexes capable of ethylene polymerization with high activity bearing either two vanadyl centers or a combination of a vanadyl/vanadium imido center. Access to bimetallic complexes possessing two vanadium imido 
centers was achieved using the imido trichloride precursors of the type $\left[\mathrm{V}(\mathrm{NAr}) \mathrm{Cl}_{3}\right](\mathrm{Ar}=p$-tolyl, $p$ $\left.\mathrm{CF}_{3} \mathrm{C}_{6} \mathrm{H}_{4}\right)$ via either salt metathesis or $\mathrm{HCl}$ elimination.

The tetra-phenolate vanadyl complexes $\mathbf{1}-\mathbf{3}$ and 5, when activated with DMAC or DEAC/ETA, showed higher activities than the benchmark catalyst $\left[\mathrm{VO}(\mathrm{OEt}) \mathrm{Cl}_{2}\right]$ for ethylene polymerization; better performances were observed in the presence of DMAC. No advantages were observed when employing meta versus the para ligation. The non-vanadyl (imido) complexes 6 and 7 performed better in the presence of DEAC and at $50{ }^{\circ} \mathrm{C}$ achieved activities as high as 230,000 g/(mmol.hr), which is the highest activity reported to-date under such robust conditions. In the case of ethylene/propylene co-polymerization, the complexes described herein gave higher molecular weight copolymer than did $\left[\mathrm{VO}(\mathrm{OEt}) \mathrm{Cl}_{2}\right]$ at comparable activity. Large variation of catalytic activity and polymer (or co-polymer) molecular weight $\left(M_{\mathrm{w}}\right)$ was observed on variation of the co-catalyst employed and whether the re-activator ETA was present or not for the various types of vanadium precatalyst deployed herein. The extremely high activities observed for these vanadium-based systems suggest that they are of potential industrial use.

\section{Experimental}

General: All manipulations were carried out under an atmosphere of dry nitrogen using conventional Schlenk and cannula techniques or in a conventional nitrogen-filled glove box. Diethyl ether and tetrahydrofuran were refluxed over sodium and benzophenone. Toluene was refluxed over sodium. Dichloromethane and acetonitrile were refluxed over calcium hydride. All solvents were distilled and degassed prior to use. IR spectra (nujol mulls, $\mathrm{KBr}$ or $\mathrm{NaCl}$ windows)

were recorded on a Nicolet Avatar 360 FT IR spectrometer; ${ }^{1} \mathrm{H}$ NMR spectra were recorded at 
room temperature on a Varian VXR $400 \mathrm{~S}$ spectrometer at $400 \mathrm{MHz}$ or a Gemini $300 \mathrm{NMR}$ spectrometer or a Bruker Advance DPX-300 spectrometer at $300 \mathrm{MHz}$. The ${ }^{1} \mathrm{H}$ NMR spectra were calibrated against the residual protio impurity of the deuterated solvent. Elemental analyses were performed by the elemental analysis service at the London Metropolitan University. The ligand $\mathrm{L}^{1} \mathrm{H}_{4}, \mathrm{~L}^{2} \mathrm{H}_{4}$ and $\mathrm{L}^{3} \mathrm{H}_{2}$ were prepared as described in the literature. [5, 23] The precursors $\left[\mathrm{V}\left(\mathrm{Np}-\mathrm{RC}_{6} \mathrm{H}_{4}\right)(\mathrm{OtBu})_{3}\right]\left(\mathrm{R}=\mathrm{Me}, \mathrm{CF}_{3}\right)$ were prepared via $\mathrm{KtOBu}$ using the method of Maatta. [16] For the polymerization studies, the dry toluene employed as a polymerization solvent was purified by passage through columns of activated alumina and BASF R3-11 oxygen scavenger. Methylaluminoxane (MAO) was purchased from Albemarle Corporation as a $1.2 \mathrm{M}$ toluene solution. This solution was dried under vacuum to remove the toluene and a substantial fraction of the $\mathrm{AlMe}_{3}$, to produce "dried MAO" (DMAO). Ethylene was obtained from Sumitomo Seika Co.

Synthesis of $\left\{[\mathrm{VO}(\mathrm{OnPr})(\mathrm{THF})]_{2}\left(\mu-p-\mathrm{L}^{1}\right)\right\} \cdot 2(\mathrm{THF})(\mathbf{1} \cdot 2(\mathrm{THF}))$

$\alpha, \alpha, \alpha^{\prime}, \alpha^{\prime}$-Tetrakis(3,5-di-tert-butyl-2-hydroxyphenyl)-p-xylene $\mathbf{L}^{\mathbf{1}} \mathrm{H}_{4}$ (4.1 g, $4.4 \mathrm{mmol}$ ) was dissolved in tetrahydrofuran $(40 \mathrm{~mL})$. Vanadium oxytri-n-propoxide (1.0 mL, $4.5 \mathrm{mmol})$ was added via syringe and the solution was stirred at room temperature for $16 \mathrm{~h}$. The volatiles were removed in vacuo, and crystallization using THF/light petroleum gave orange plates of the compound 1 (2.6 g, 45 \%). MS (EI, m/z) 1170.6 [M-2THF] $]^{+}, 1110.5$ [M-OnPr-2THF] $]^{+}, 1068.5$ $[\mathrm{M}-n \operatorname{Pr}-\mathrm{OnPr}-2 \mathrm{THF}]^{2+}$. IR (Nujol, KBr, $\mathrm{cm}^{-1}$ ): 1597w, 1507m, 1435s, 1402w, 1286w, 1261m, 1221s, 1203s, 1153m, 1118s, 1104s, 1027s, 989s, 908m, 891m, 876s, 837s, 801m, 777m, 767m, 750m, 736w, 702w, 659s, 603m, 578w. Found: C, 71.61; H, 8.42. $\mathrm{C}_{70} \mathrm{H}_{100} \mathrm{O}_{8} \mathrm{~V}_{2}$ (sample dried in 
vacuo for $24 \mathrm{~h}$ leads to loss of THF x2) requires $\mathrm{C}, 71.77 ; \mathrm{H}, 8.60 \% .{ }^{1} \mathrm{H}$ NMR $\left(\mathrm{CDCl}_{3}\right)$ : $\delta=7.31$ (d, 4H, $J=2.33$, aryl $H$ ), 7.22 (d, 4H, $J=2.33$, aryl $H$ ), 6.78 (s, 4H, aryl $H$ ), 6.31 (s, 2H, $\mathrm{Ar}_{3}-\mathrm{CH}$ ), $5.36\left(\mathrm{t}, 4 \mathrm{H}, J=6.00, \mathrm{OCH}_{2} \mathrm{CH}_{2}\right.$ ), $3.75(\mathrm{bm}, 8 \mathrm{H}, \mathrm{THF} \alpha-H)$, 1.98 (sextet, $4 \mathrm{H}, J=6.73$, $\mathrm{CH}_{2} \mathrm{CH}_{2} \mathrm{CH}_{3}$ ), 1.86 (bm, 8H, THF $\beta-H$ ), 1.40 (s, 36H, $t \mathrm{Bu}$ ), 1.24 (s, 36H, $t \mathrm{Bu}$ ), 1.08 (t, $6 \mathrm{H}, J=$ 7.35, $\left.\mathrm{CH}_{2} \mathrm{CH}_{3}\right) .{ }^{51} \mathrm{~V}$ NMR $\left(\mathrm{CDCl}_{3}\right): \delta=-433.3\left(w_{1 / 2}=170 \mathrm{~Hz}\right)$.

\section{Synthesis of $\left\{\mathbf{L}^{\mathbf{1}}[\mathrm{VO}(t \mathrm{BuO})]_{2}\right\} \cdot 2 \mathrm{MeCN}(2 \cdot 2 \mathrm{MeCN})$}

$\mathbf{L}^{1} \mathrm{H}_{4}(4.1 \mathrm{~g}, 4.4 \mathrm{mmol})$ and $\left[\mathrm{VO}(\mathrm{BuO})_{3}\right](3.20 \mathrm{~g}, 8.90 \mathrm{mmol})$ were refluxed in toluene $(30 \mathrm{ml})$ for $12 \mathrm{~h}$. On cooling, volatiles were removed in-vacuo and the residue can be extracted into either acetonitrile or dichloromethane $(30 \mathrm{ml})$. Prolonged standing at $0{ }^{\circ} \mathrm{C}$ afforded 2 as a brown solid in $66 \%$ (3.72 g) yield. $\mathrm{C}_{72} \mathrm{H}_{104} \mathrm{~V}_{2} \mathrm{O}_{8} \cdot 0.75 \mathrm{CH}_{2} \mathrm{Cl}_{2}$ (sample dried in-vacuo for $2 \mathrm{~h}$ ) requires $\mathrm{C}$ 69.17, H, 8.42. Found C, 68.84, H 8.77 \%. MS (solid, APCI) [24]: m/z 1199.6 [M] $]^{+}, 1125.6$ [MOtBu $]^{+}, 1069.5[\mathrm{M}-\mathrm{O} t \mathrm{Bu}-\mathrm{tBu}]^{2+} . \mathrm{IR}: 1594 \mathrm{w}, 1568 \mathrm{w}, 1508 \mathrm{w}, 1401 \mathrm{~m}, 1291 \mathrm{~m}, 1261 \mathrm{~s}, 1236 \mathrm{~m}$, 1224s, 1211m, 1200m, 1153s, 1118s, 1104s, 1021m, 1004s, 969bs, 911m, 876s, 845s, 826w, 800m, 777w, 768s, 731m, 722m, 705w, 668m, 653w, 644w, 604m, 542w, 497w, 467w. ${ }^{1} \mathrm{H}$ NMR $\left(\mathrm{CDCl}_{3}\right): \delta=7.30-7.21(3 \mathrm{x} \mathrm{m}, 8 \mathrm{H}, \operatorname{aryl} H), 6.75$ (s, 4H, aryl $\left.H\right), 6.34$ (s, 2H, CH), 5.64 (s, 4H, 2x $\left.\mathrm{CH}_{2} \mathrm{Cl}_{2}\right), 1.69$ (s, 18H, OC( $\left.\left(\mathrm{CH}_{3}\right)_{3}\right), 1.43\left(\mathrm{~s}, 36 \mathrm{H}, \mathrm{C}\left(\mathrm{CH}_{3}\right)_{3}\right), 1.22$ (s, 36H, $\left.\mathrm{C}\left(\mathrm{CH}_{3}\right)_{3}\right) .{ }^{51} \mathrm{~V}$ NMR $\left(\mathrm{CDCl}_{3}\right) \delta=-467.9\left(w_{1 / 2}=528 \mathrm{~Hz}\right)$. Single crystals of $2.2 \mathrm{MeCN}$ were grown from a saturated acetonitrile solution on prolonged standing at $0{ }^{\circ} \mathrm{C}$. 
Synthesis of $\left\{\mathbf{L}^{2}[\mathrm{VO}(\mathrm{OnPr})(\mathrm{THF})]_{2}\right\}$ (3)

As for 1, but using $\alpha, \alpha, \alpha^{\prime}, \alpha^{\prime}$-tetrakis(3,5-di-tert-butyl-2-hydroxyphenyl)-m-xylene $\left(\mathbf{L}^{2} \mathrm{H}_{4}, 4.1 \mathrm{~g}\right.$, $4.4 \mathrm{mmol})$ and vanadium oxytri- $n$-propoxide $(1.0 \mathrm{~mL}, 4.5 \mathrm{mmol})$. Crystallization using THF/light petroleum afforded orange needles of 3 (2.0 g, 35 \%). MS (E.I.): 1170.6 [M-2THF] ${ }^{+}$, 1110.5 [M-HOnPr-2THF] ${ }^{+}$. IR (Nujol, KBr, $\mathrm{cm}^{-1}$ ): 1595m, 1406m, 1361s, 1217s, 1154m, 1118s, 1104s, 1030s, 992s, 910w, 882w, 846s, 787s, 720s, 695w, 649s, 601m, 499w, 449w. Found: C, 71.60; $\mathrm{H}, 8.41 . \mathrm{C}_{70} \mathrm{H}_{100} \mathrm{O}_{8} \mathrm{~V}_{2}$ (sample dried in vacuo for $24 \mathrm{~h}$ leads to loss of THF x2) requires $\mathrm{C}$, 71.76; H, $8.60 \% .{ }^{1} \mathrm{H}$ NMR $\left(\mathrm{CDCl}_{3}\right): \delta=7.18$ (d, 4H, $J=2.35$, aryl $\left.H\right), 7.15$ (d, 4H, $J=2.35$, $\operatorname{aryl} H$ ), 7.10 (s, $1 \mathrm{H}$, aryl $H$ ), 7.02 (t, $1 \mathrm{H}, J=7.83$, aryl $H$ ), 6.80 (d, $2 \mathrm{H}, J=7.93$, aryl $H), 6.25$ (s, 2H, $\mathrm{Ar}_{3}-\mathrm{CH}$ ), 5.34 (t, 4H, $J=6.53, \mathrm{OCH}_{2} \mathrm{CH}_{2}$ ), 3.74 (bm, 8H, THF $\left.\alpha-H\right), 1.98$ (sextet, $4 \mathrm{H}, J=$ 7.00, $\mathrm{CH}_{2} \mathrm{CH}_{2} \mathrm{CH}_{3}$ ), 1.86 (bm, 8H, THF $\beta-H$ ), 1.42 (s, 36H, $\left.t \mathrm{Bu}\right), 1.17$ (s, 36H, $\left.t \mathrm{Bu}\right), 1.09$ (t, 6H, $\left.\mathrm{J}=7.35, \mathrm{CH}_{2} \mathrm{CH}_{3}\right) .{ }^{51} \mathrm{~V} \mathrm{NMR}\left(\mathrm{CDCl}_{3}\right) \delta=-432.5\left(w_{1 / 2}=170 \mathrm{~Hz}\right)$.

Synthesis of $\left\{[\mathrm{VO}(t \mathrm{BuO})]\left[\mathrm{V}\left(\mathrm{Np}-\mathrm{MeC}_{6} \mathrm{H}_{4}\right)(t \mathrm{BuO})\right]\left(\mu-p-\mathrm{L}^{1}\right)\right\} \cdot \mathrm{CH}_{2} \mathrm{Cl}_{2}\left(\mathbf{4} \cdot \mathrm{CH}_{2} \mathrm{Cl}_{2}\right)$

[V(Np- $\left.\mathrm{MeC}_{6} \mathrm{H}_{4}(\mathrm{OtBu})_{3}\right](3.3 \mathrm{~g}, 8.8 \mathrm{mmol})$ and $\mathrm{L}^{1} \mathrm{H}_{4}(4.1 \mathrm{~g}, 4.4 \mathrm{mmol})$ were refluxed in toluene (30 mL) for $12 \mathrm{~h}$. On cooling, the volatiles were removed in-vacuo, and the residue was extracted into either acetonitrile $(30 \mathrm{ml})$ or dichloromethane $(30 \mathrm{ml})$. Cooling to $-20{ }^{\circ} \mathrm{C}$ afforded 4 as small yellow/orange crystals. Yield 2.05 g, $34 \%$. $\mathrm{C}_{79} \mathrm{H}_{111} \mathrm{NO}_{7} \mathrm{~V}_{2} \cdot 2 \mathrm{CH}_{2} \mathrm{Cl}_{2}$ requires $\mathrm{C} 66.70$, H 7.95, N, 0.96 \%. Found C 66.22, H 8.32, N, 1.02 \%. MS (solvated with $\mathrm{CH}_{2} \mathrm{Cl}_{2}$ and diluted with MeCN for positive nano-electrospray technique): $\mathrm{m} / \mathrm{z} 1291[\mathrm{M}]^{+}, 1185\left[\mathrm{M}-\mathrm{H}_{2} \mathrm{~Np}-\mathrm{C}_{6} \mathrm{H}_{4}\right]^{+}$. IR: 1593w, 1568w, 1508w, 1403m, 1362s, 1291m, 1261s, 1238w, 1224m, 1201w, 1153m, 1115m, 1104s, 1018s, 974s, 912w, 876m, 844m, 800s, 778m, 769m, 737m, 705w, 669w, 644w, 603w, 
573w, 542w, 468w. ${ }^{1} \mathrm{H}$ NMR $\left(\mathrm{CDCl}_{3}\right): \delta=7.22-7.13(3 \mathrm{x} \mathrm{m}, 12 \mathrm{H}$, aryl $H)$, $6.68(\mathrm{~s}, 4 \mathrm{H}$, aryl $H$ ), 6.27 (s, 2H, $\mathrm{CH}$ ), 5.22 (s, 2H, $\mathrm{CH}_{2} \mathrm{Cl}_{2}$ ), 2.23 (s, 3H, tolylCH$)_{3}$ ), 1.93 (s, 3H, $\mathrm{CH}_{3} \mathrm{CN}$ ), 1.69 (s, 18H, OC( $\left.\left(\mathrm{CH}_{3}\right)_{3}\right), 1.44$ (overlapping s, 27H, $\left.\mathrm{C}\left(\mathrm{CH}_{3}\right)_{3}\right), 1.36$ (s, 9H, $\left.\mathrm{C}\left(\mathrm{CH}_{3}\right)_{3}\right), 1.23$ (overlapping s, 27H, $\left.\mathrm{C}\left(\mathrm{CH}_{3}\right)_{3}\right), 1.15$ (s, 9H, C(CH $\left.)_{3}\right) ;{ }^{51} \mathrm{~V}$ NMR $\left(\mathrm{CDCl}_{3}\right) \delta=-468.2\left(w_{1 / 2}=277 \mathrm{~Hz}\right),-558.5$ $\left(w_{1 / 2}=297 \mathrm{~Hz}\right)$.

Synthesis of $\left\{[\mathrm{VO}(t \mathrm{BuO})]\left[\mathrm{V}\left(\mathrm{Np}-\mathrm{CF}_{3} \mathrm{C}_{6} \mathrm{H}_{4}\right)(t \mathrm{BuO})\right]\left(\mu-p-\mathrm{L}^{1}\right)\right\} \cdot \mathrm{CH}_{2} \mathrm{Cl}_{2}\left(5 \cdot \mathrm{CH}_{2} \mathrm{Cl}_{2}\right)$ As for 7, but using $\left[\mathrm{V}\left(\mathrm{Np}-\mathrm{CF}_{3} \mathrm{C}_{6} \mathrm{H}_{4}(\mathrm{OtBu})_{3}\right](3.8 \mathrm{~g}, 8.8 \mathrm{mmol})\right.$ and $\mathrm{L}^{1} \mathrm{H}_{4}(4.1 \mathrm{~g}, 4.4 \mathrm{mmol})$ affording on cooling $\left(-20{ }^{\circ} \mathrm{C}\right) \mathbf{5}$ as pale yellow/orange needles (yield $2.57 \mathrm{~g}, 41 \%$ ). $\mathrm{C}_{79} \mathrm{H}_{106} \mathrm{~F}_{3} \mathrm{NO}_{7} \mathrm{~V}_{2} \cdot \mathrm{CH}_{2} \mathrm{Cl}_{2}$ requires $\mathrm{C}, 67.40, \mathrm{H}, 7.64, \mathrm{~N}, 0.98 \%$. Found $\mathrm{C}$ 67.33, H 7.77, $\mathrm{N}$ $0.89 \%$. MS (solvated with $\mathrm{CH}_{2} \mathrm{Cl}_{2}$ and diluted with $\mathrm{MeCN}$ for positive nano-electrospray technique): m/z $1342[\mathrm{MH}]^{+}$, 1269 [MH-OtBu]. IR: 1623w, 1599w, 1526w, 1507w, 1402m, 1375s, 1362s, 1327s, 1320s, 1292m, 1259s, 1237m, 1213m, 1200m, 1152s, 1117s, 1104s, 1066s, 976s, 911m, 873m, 841s, 801s, 768s, 755w, 735w, 720w, 705w, 696w, 667m, 652w, 643w, 621w, 597m, 573w, 540w, 503w, 494w. ${ }^{1} \mathrm{H}$ NMR $\left(\mathrm{CDCl}_{3}\right): \delta=7.33-7.13(3 \mathrm{x} \mathrm{m}, 8 \mathrm{H}, \operatorname{aryl} H)$, 6.68 (s, 4H, arylH), 6.27 (s, 2H, CH), 5.22 (s, 2H, $\mathrm{CH}_{2} \mathrm{Cl}_{2}$ ), 1.93 (s, 3H, $\mathrm{CH}_{3} \mathrm{CN}$ ), 1.69 (s, $18 \mathrm{H}$, OC( $\left.\left(\mathrm{CH}_{3}\right)_{3}\right), 1.53$ (s, 9H, C(CH3) $\left.)_{3}\right), 1.37$ (s, 27H, $\left.\mathrm{C}\left(\mathrm{CH}_{3}\right)_{3}\right), 1.23$ (s, 9H, $\left.\mathrm{C}\left(\mathrm{CH}_{3}\right)_{3}\right), 1.17$ (s, 27H, $\left.\mathrm{C}\left(\mathrm{CH}_{3}\right)_{3}\right) ;{ }^{19} \mathrm{~F} \mathrm{NMR}\left(\mathrm{CDCl}_{3}\right) \delta=-61.2 ;{ }^{51} \mathrm{~V} \mathrm{NMR}\left(\mathrm{CDCl}_{3}\right) \delta=-467.7\left(w_{1 / 2}=520 \mathrm{~Hz}\right),-539.6$ $\left(w_{1 / 2}=296 \mathrm{~Hz}\right)$. 
Synthesis of $\left\{\left[\mathrm{V}(\mathrm{THF})\left(\mathrm{N} p-\mathrm{MeC}_{6} \mathrm{H}_{4}\right) \mathrm{Cl}\right]_{2}\left(\mu-p-\mathrm{L}^{1}\right)\right\}$ 6-4toluene

$\mathrm{L}^{1} \mathrm{H}_{4}(1.00 \mathrm{~g}, 1.08 \mathrm{mmol})$ and $\mathrm{Na}(0.10 \mathrm{~g}, 4.35 \mathrm{mmol})$ were stirred in THF $(30 \mathrm{ml})$ at ambient temperature for $12 \mathrm{~h}$. The solution was then cooled to $-78{ }^{\circ} \mathrm{C}$ and solid $\left[\mathrm{V}\left(\mathrm{Np}-\mathrm{MeC}_{6} \mathrm{H}_{4}\right) \mathrm{Cl}_{3}\right]$ ( $0.60 \mathrm{~g}, 2.29 \mathrm{mmol}$ ) was added. The mixture was allowed to warm to room temperature and was stirred for $12 \mathrm{~h}$. Volatiles were removed in-vacuo, and the residue was extracted into toluene (30 $\mathrm{ml}$ ) or dichloromethane $(30 \mathrm{ml})$. Brown/red prisms of 6 were formed on prolonged standing (1 2 days) at $0{ }^{\circ} \mathrm{C}$. Yield: $1.61 \mathrm{~g}, 83 \%$. $\mathrm{C}_{87} \mathrm{H}_{102} \mathrm{Cl}_{2} \mathrm{~N}_{2} \mathrm{O}_{6} \mathrm{~V}_{2}$ (sample crystallized from $\mathrm{CH}_{2} \mathrm{Cl}_{2}$, 6. $\mathrm{CH}_{2} \mathrm{Cl}_{2}$ ) requires C, 68.95, H, 6.78, N, 1.84 \%. Found C 69.92*, H 7.16, N 2.05 \%. * Despite repeated attempts, we were unable to obtain closer \%C values. MS (EI, positive mode): $\mathrm{m} / \mathrm{z} 1527$ ( $\left.\mathrm{M}^{+}-\mathrm{Cl}-\mathrm{THF}\right), 1459\left(\mathrm{M}^{+}-2 \mathrm{Cl}-\right.$ tolylNH$\left.{ }_{2}\right)$. IR: 3544w, 1597w, 1568m, 1506w, 1291m, 1261s, 1240m, 1224m, 1201w, 1153w, 1118m, 1104m, 1007s, 968s, 912w, 876m, 844m, 799m, 778w, 768m, 722s, 668w, 643w, 603w, 496w, 462w. ${ }^{1} \mathrm{H}$ NMR $\left(\mathrm{CDCl}_{3}\right): \delta=7.45-6.92(3 \mathrm{x} \mathrm{m}, 17 \mathrm{H}$, arylH including one toluene), 6.56 (s, 2H, CH), 6.49 (d, J $8.0 \mathrm{~Hz}, 4 \mathrm{H}$, arylH), 5.97 (d, J $8.0 \mathrm{~Hz}$, 4H, arylH), 4.29 (m, 8H, THF $\alpha-\mathrm{H}$ ), 2.37 (s, $6 \mathrm{H} . \mathrm{CH}_{3} \mathrm{C}_{6} \mathrm{H}_{4}$ ), 2.17 (s, 3H, $\mathrm{CH}_{3}$ of toluene), 2.02 (m, 8H, THF $\beta-\mathrm{H}), 1.31$ (s, 36H, C $\left.\left(\mathrm{CH}_{3}\right)_{3}\right), 1.23\left(\mathrm{~s}, 36 \mathrm{H}, \mathrm{C}\left(\mathrm{CH}_{3}\right)_{3}\right) ;{ }^{51} \mathrm{~V} \mathrm{NMR}\left(\mathrm{CDCl}_{3}\right) \delta=-7.3$ $\left(w_{1 / 2}=3373 \mathrm{~Hz}\right)$.

\section{Synthesis of $\left\{\left[\mathrm{V}(\mathrm{THF})\left(\mathrm{N} p-\mathrm{CF}_{3} \mathrm{C}_{6} \mathrm{H}_{4}\right) \mathrm{Cl}\right]_{2}\left(\mu-p-\mathrm{L}^{1}\right)\right\} 7$}

As for 8, but using $\left[\mathrm{V}\left(\mathrm{Np}-\mathrm{CF}_{3} \mathrm{C}_{6} \mathrm{H}_{4}\right) \mathrm{Cl}_{3}\right](0.72 \mathrm{~g}, 2.28 \mathrm{mmol})$ and $\mathrm{L}^{1} \mathrm{H}_{4}(1.00 \mathrm{~g}, 1.08 \mathrm{mmol})$ and $\mathrm{Et}_{3} \mathrm{~N}$ (0.63 ml, $4.55 \mathrm{mmol}$ ) affording red/brown 7; the complex can be recrystallized from cold toluene or dichloromethane, yield $0.71 \mathrm{~g}, 47 \%$. $\mathrm{C}_{114} \mathrm{H}_{126} \mathrm{Cl}_{2} \mathrm{~F}_{6} \mathrm{~N}_{2} \mathrm{O}_{6} \mathrm{~V}_{2} \cdot \mathrm{CH}_{2} \mathrm{Cl}_{2}$ requires $\mathrm{C}$, 63.73, H, 6.89, N, 1.71 \%. Found C 63.56, H 7.20, N 1.47 \%. MS (EI, positive mode) 1411.5 [MH - 
$2 \mathrm{THF}]^{+}, 1340.6[\mathrm{MH}-2 \mathrm{THF}-2 \mathrm{Cl}]^{+}, 1250\left[\mathrm{MH}-2 \mathrm{THF}-\mathrm{H}_{2} \mathrm{NC}_{6} \mathrm{H}_{4} \mathrm{CF}_{3}\right]^{+}, 1089[\mathrm{MH}-2 \mathrm{THF}$ $\left.-2 \mathrm{H}_{2} \mathrm{NC}_{6} \mathrm{H}_{4} \mathrm{CF}_{3}\right]^{+}$. IR: 2335w, 1693w, 1651w, 1616w, 1600w, 1507w, 1406m, 1364s, 1321s, 1261s, 1240w, 1226m, 1201w, 1168s, 1122s, 1104s, 1066s, 1021s, 956w, 910w, 873m, 841s, 803s, 773m, 753w, 728s, 692m, 668w, 645w, 626w, 596m, 556w, 502w, 464w. ${ }^{1} \mathrm{H}$ NMR $\left(\mathrm{CDCl}_{3}\right): \delta=7.54-7.02(3 \mathrm{x} \mathrm{m}, 16 \mathrm{H}$, aryl $H+$ imidoaryl $H), 6.76(\mathrm{~s}, 4 \mathrm{H}$, aryl $H), 6.35(\mathrm{~s}, 2 \mathrm{H}, \mathrm{CH})$, 5.29 (s, 2H, $\mathrm{CH}_{2} \mathrm{Cl}_{2}$ ), 3.12 (bm, 8H, THF $\left.\alpha-H\right), 1.85$ (bm, 8H, THF $\left.\beta-H\right), 1.43$ (s, 36H, $\left.\mathrm{C}\left(\mathrm{CH}_{3}\right)_{3}\right)$, $1.23\left(\mathrm{~s}, 36 \mathrm{H}, \mathrm{C}\left(\mathrm{CH}_{3}\right)_{3}\right) ;{ }^{19} \mathrm{~F}$ NMR $\left(\mathrm{CDCl}_{3}\right) \delta=-60.7 ;{ }^{51} \mathrm{~V}$ NMR $\left(\mathrm{C}_{6} \mathrm{D}_{6}\right) \delta=-211.1\left(w_{1 / 2}=647\right.$ $\mathrm{Hz})$.

Synthesis of $\left\{\mathbf{L}^{3}(\mathrm{VO})_{2}(\mu-\mathrm{OnPr})_{2}\right\}$ (8)

2-( $\alpha$-(2-Hydroxy-3,5-di-tert-butylphenyl)benzyl)-4,6-di-tert-butylphenol $\left(\mathbf{L}^{3} \mathrm{H}_{2}, 4.1\right.$ g, $\left.8.2 \mathrm{mmol}\right)$ was dissolved in tetrahydrofuran $(40 \mathrm{~mL})$. Vanadium oxytri- $n$-propoxide $(1.9 \mathrm{~mL}, 8.4 \mathrm{mmol})$ was added via syringe and the solution was stirred at room temperature for $16 \mathrm{~h}$. The volatiles were removed in vacuo, following which crystallization using warm light petroleum gave red needles of the vanadium dimer 8 (3.6 g, 70 \%). MS (EI, m/z): 624.4 [M] $]^{+}, 564.4$ [M-OnPr]. IR (Nujol, KBr, $\mathrm{cm}^{-1}$ ): 1599m, 1381m, 1289w, 1220s, 1153s, 1103s, 1060s, 989s, 911w, 875w, 855m, 836s, 800m, 770m, 745m, 705m, 652s, 599m, 503w, 451w. Found: C, 72.82; H, 8.39. $\mathrm{C}_{76} \mathrm{H}_{106} \mathrm{O}_{8} \mathrm{~V}_{2}$ requires $\mathrm{C}, 73.05 ; \mathrm{H}, 8.55 \% .{ }^{1} \mathrm{H} \mathrm{NMR}\left(\mathrm{CDCl}_{3}\right): \delta=7.33(\mathrm{~d}, 4 \mathrm{H}, J=2.30$, aryl $H)$, 7.27 d, $(4 \mathrm{H}, J=2.30$, aryl $H$ ), 7.21-7.15 (m, 4H, aryl $H$ ), 7.00 (d, 4H, $J=7.95$, aryl $H$ ), 6.38 (s, 2H, $\mathrm{Ar}_{3} \mathrm{CH}$ ), 5.37 (t, 4H, $J=6.03, \mathrm{OCH}_{2} \mathrm{CH}_{2}$ ), 1.99 (sextet, 4H, $\mathrm{CH}_{2} \mathrm{CH}_{2} \mathrm{CH}_{3}$ ), 1.47 (s, 36H, $t \mathrm{Bu}$ ), $1.26(\mathrm{~s}, 36 \mathrm{H}, t \mathrm{Bu}), 1.10\left(\mathrm{t}, 6 \mathrm{H}, J=7.40, \mathrm{CH}_{2} \mathrm{CH}_{3}\right) .{ }^{51} \mathrm{~V} \mathrm{NMR}\left(\mathrm{CDCl}_{3}\right): \delta=-433.6\left(w_{1 / 2}=170\right.$ $\mathrm{Hz})$. 


\section{Polymer Characterization}

The melt transition temperatures $\left(T_{\mathrm{m}}\right)$ of the polyethylene (PE) and ethylene/propylene copolymer (EPR) were determined by differential scanning calorimetry (DSC) with a Shimadzu DSC-60 instrument. The polymer samples were heated at $50{ }^{\circ} \mathrm{C} / \mathrm{min}$ from $20{ }^{\circ} \mathrm{C}$ to $200{ }^{\circ} \mathrm{C}$, held at $200{ }^{\circ} \mathrm{C}$ for $5 \mathrm{~min}$, and cooled to $0{ }^{\circ} \mathrm{C}$ at $20{ }^{\circ} \mathrm{C} / \mathrm{min}$. The samples were held at this temperature for $5 \mathrm{~min}$, and then reheated to $200{ }^{\circ} \mathrm{C}$ at $10{ }^{\circ} \mathrm{C} / \mathrm{min}$. The reported $T_{\mathrm{m}}$ was determined from the second heating scan unless otherwise noted.

Molecular weights ( $M_{\mathrm{w}}$ and $M_{\mathrm{n}}$ ) and molecular weight distributions (MWDs) of PE and EPR were determined using a Waters GPC2000 gel permeation chromatograph equipped with four TSKgel columns (two sets of TSKgelGMH ${ }_{6}-\mathrm{HT}$ and two sets of TSKgelGMH ${ }_{6}-\mathrm{HTL}$ ) at $140{ }^{\circ} \mathrm{C}$ using polyethylene calibration. $o$-Dichlorobenzene (ODCB) was used as the solvent.

Polymerization Procedure: Polymerization reactions were performed in a parallel pressure reactor (Argonaut Endeavor ${ }^{\circledR}$ Catalyst Screening System) containing 8 reaction vessels (15 mL) each equipped with a mechanical stirrer and monomer feed lines. At first, a toluene solution (and a toluene solution of ETA where necessary) were injected into each vessel. For ethylene polymerization, the solution was heated to the polymerization temperature $\left(T_{\mathrm{p}}\right)$ and thermally equilibrated, and the nitrogen atmosphere was replaced with ethylene and the solution was saturated with ethylene at the polymerization pressure. For ethylene/propylene copolymerization, the solution was heated to the $T_{\mathrm{p}}$ and thermally equilibrated, and the nitrogen atmosphere was replaced with propylene and the reaction vessels were pressurized with propylene (0.4 MPa at 25 $\left.{ }^{\circ} \mathrm{C}\right)$, then ethylene was introduced into the reactor up to the polymerization pressure. In all cases 
the polymerization was started by addition of a toluene solution of alkyl aluminum or alkyl aluminum chloride followed by addition of a toluene solution of the vanadium complex $(0.50$ $\mathrm{mL}$ toluene solution of complex followed by $0.25 \mathrm{~mL}$ toluene wash). The total volume of the reaction mixture was $5 \mathrm{~mL}$ for all polymerizations. The pressure was kept constant by feeding ethylene on demand. After the reaction, the polymerization was stopped by addition of excess isobutyl alcohol. The resulting mixture was added to acidified methanol (45 ml containing $0.5 \mathrm{ml}$ of concentrated $\mathrm{HCl})$. The polymer was recovered by filtration, washed with methanol $(2 \times 10$ $\mathrm{ml}$ ) and dried in a vacuum oven at $80{ }^{\circ} \mathrm{C}$ for $10 \mathrm{~h}$.

Crystallography: Single crystal X-ray diffraction data for 7.toluene.thf were collected in series of $\omega$-scans using a Stoe IPSD2 image plate diffractometer utilising monochromated Mo radiation $(\lambda$ $=0.71073 \AA$ ). Standard procedures were employed for the integration and processing of the data using X-RED. [25] Samples were coated in a thin film of perfluoropolyether oil and mounted at the tip of a glass fibre located on a goniometer. Data were collected from crystals held at $150 \mathrm{~K}$ in an Oxford Cryosystems nitrogen gas cryostream.

All other single crystal data were collected using series of $\omega$-scans by the EPSRC UK National Crystallography Service; data for 3 was collected at the Diamond Light Source (I19, synchrotron radiation $\lambda=0.6889 \AA$ ); data for the remaining samples were collected using a radiation from a Mo rotating anode source. Samples were mounted using MiTeGen loops and held at $100 \mathrm{~K}$ in an Oxford Cryosystems nitrogen gas cryostream. Data were corrected for Lp effects and for absorption. CrystalClear-SM Expert 3.1 b27 (Rigaku, 2012); cell refinement: CrystalClear-SM Expert 3.1 b27 (Rigaku, 2012); data reduction: CrystalClear-SM Expert 3.1 b27 (Rigaku, 2012); 
program(s) used to solve structure: SHELXS97 [26]; program(s) used to refine structure: SHELXL2013 [27]

Many of the structures contained small-scale disorder involving the t-butyl groups. This was handled using standard procedures. The SQUEEZE [28] routine was applied to model scattering from regions of disordered solvent in these structures: $\mathbf{3}$ and $\mathbf{8}$. The crystal examined for 6. MeCN was found to be twinned and this was handled by routine techniques and the final model refined using the HKLF5 formalism using all observed data.

CCDC 1404522-3, 1404527-8 and 1404530-2 (structures 1 \& 3, 4 \& 5, 6 - 8) and 1048777 (structure 2) contain the supplementary crystallographic data for this paper. These data can be obtained free of charge from The Cambridge Crystallographic Data Centre via www.ccdc.cam.ac.uk/data_request/cif.

Acknowledgements: The EPSRC Mass Spectrometry Service (Swansea, UK) and the EPSRC National X-ray Crystallographic Service (Southampton) are thanked for data collection. CR thanks the EPSRC for an Overseas Travel grant.

Supporting Information Available: X-ray crystallographic files CIF format for the structure determinations of compounds 1·2THF, 2·2MeCN, 3, $\mathbf{4} \cdot \mathrm{CH}_{2} \mathrm{Cl}_{2}, \mathbf{5} \cdot \mathrm{CH}_{2} \mathrm{Cl}_{2}, \mathbf{6} \cdot$ 4toluene, 7 and 8.

Table 6. Crystallographic data for the complexes $1 \cdot 2 \mathrm{THF}, 2 \cdot 2 \mathrm{MeCN}$ and 3.

\begin{tabular}{llll}
\hline Compound & $\mathbf{1} \cdot 2$ (THF) & $\mathbf{2} \cdot 2 \mathrm{MeCN}$ & $\mathbf{3}$ \\
\hline Formula & $\mathrm{C}_{78} \mathrm{H}_{116} \mathrm{~V}_{2} \mathrm{O}_{10} \cdot 2 \mathrm{C}_{4} \mathrm{H}_{8} \mathrm{O}$ & $\mathrm{C}_{72} \mathrm{H}_{104} \mathrm{~V}_{2} \mathrm{O}_{8} \cdot 2 \mathrm{CH}_{3} \mathrm{CN}$ & $\mathrm{C}_{78} \mathrm{H}_{116} \mathrm{~V}_{2} \mathrm{O}_{10}$
\end{tabular}




\begin{tabular}{|c|c|c|c|}
\hline Formula weight & 1459.80 & 1281.53 & 1315.66 \\
\hline Crystal system & orthorhombic & triclinic & monoclinic \\
\hline Space group & Pbca & $P \overline{1}$ & $P 2 / n$ \\
\hline \multicolumn{4}{|l|}{$\begin{array}{l}\text { Unit cell } \\
\text { dimensions }\end{array}$} \\
\hline$a(\AA)$ & 23.8164(16) & $9.1413(7)$ & $20.18(2)$ \\
\hline$b(\AA)$ & 18.9585(7) & $11.0130(8)$ & $15.820(16)$ \\
\hline$c(\AA)$ & $18.6002(6)$ & 18.8731(13) & $26.50(3)$ \\
\hline$\alpha\left(^{\circ}\right)$ & 90 & $74.468(8)$ & 90 \\
\hline$\beta\left(^{\circ}\right)$ & 90 & 89.494(9) & $110.686(11)$ \\
\hline$\gamma\left({ }^{\circ}\right)$ & 90 & $85.010(9)$ & 90 \\
\hline$V\left(\AA^{3}\right)$ & 8398.4(7) & $1823.5(20$ & 7915(14) \\
\hline$Z$ & 4 & 1 & 4 \\
\hline Temperature (K) & $100(2)$ & $100(2)$ & $100(2)$ \\
\hline Wavelength ( $\AA$ ) & 0.71075 & 0.71075 & 0.71075 \\
\hline $\begin{array}{l}\text { Calculated } \\
\text { density } \\
\left(\mathrm{g} . \mathrm{cm}^{-3}\right)\end{array}$ & 1.155 & 1.167 & 1.021 \\
\hline $\begin{array}{l}\text { Absorption } \\
\text { coefficient } \\
\left(\mathrm{mm}^{-1}\right)\end{array}$ & 0.279 & 0.309 & 0.264 \\
\hline $\begin{array}{l}\text { Transmission } \\
\text { factors } \\
\text { (min./max.) }\end{array}$ & 0.9753 and 0.9917 & 0.642 and 1.000 & 0.355 and 1.000 \\
\hline $\begin{array}{l}\text { Crystal size } \\
\left(\mathrm{mm}^{3}\right)\end{array}$ & $0.09 \times 0.08 \times 0.03$ & $0.06 \times 0.05 \times 0.01$ & $0.04 \times 0.04 \times 0.01$ \\
\hline$\theta(\max )\left(^{\circ}\right)$ & 27.46 & 25.601 & 18.06 \\
\hline $\begin{array}{l}\text { Reflections } \\
\text { measured }\end{array}$ & 57655 & 28762 & 30414 \\
\hline $\begin{array}{l}\text { Unique } \\
\text { reflections }\end{array}$ & 9280 & 6855 & 6040 \\
\hline$R_{\mathrm{int}}$ & 0.1195 & 0.0975 & 0.2574 \\
\hline $\begin{array}{l}\text { Reflections with } \\
F^{2}>2 \sigma\left(F^{2}\right)\end{array}$ & 5352 & 3107 & 3038 \\
\hline Number $\quad 0$ & 464 & 388 & 578 \\
\hline
\end{tabular}


parameters

$\begin{array}{lllc}R_{1}\left[F^{2}>2 \sigma\left(F^{2}\right)\right] & 0.0484 & 0.1541 & 0.2176 \\ w R_{2} \text { (all data) } & 0.1110 & 0.4724 & 0.5275 \\ \text { GOOF, } S & 0.913 & 1.431 & 1.522 \\ \text { Largest difference } & & & 0.777 \text { and }-0.463 \\ \text { peak and hole (e } & 0.346 \text { and }-0.454 & 0.514 \text { and }-0.871 & \end{array}$

Table 6 con't. Crystallographic data for the complexes $\mathbf{4} \cdot \mathrm{CH}_{2} \mathrm{Cl}_{2}$ and $\mathbf{5} \cdot \mathrm{CH}_{2} \mathrm{Cl}_{2}$

\begin{tabular}{|c|c|c|}
\hline Compound & $4 \cdot \mathrm{CH}_{2} \mathrm{Cl}_{2}$ & 5. $\mathrm{CH}_{2} \mathrm{Cl}_{2}$ \\
\hline Formula & $\mathrm{C}_{79} \mathrm{H}_{111} \mathrm{NV}_{2} \mathrm{O}_{7} \cdot \mathrm{CH}_{2} \mathrm{Cl}_{2}$ & $\mathrm{C}_{79} \mathrm{H}_{106} \mathrm{NF}_{3} \mathrm{~V}_{2} \mathrm{O}_{7} \cdot \mathrm{CH}_{2} \mathrm{Cl}_{2}$ \\
\hline Formula weight & 1373.49 & 1425.45 \\
\hline Crystal system & triclinic & triclinic \\
\hline Space group & $P \overline{1}$ & $P \overline{1}$ \\
\hline \multicolumn{3}{|l|}{ Unit cell dimensions } \\
\hline$a(\AA)$ & $9.4460(6)$ & $9.413(7)$ \\
\hline$b(\AA)$ & $11.1800(7)$ & $11.244(8)$ \\
\hline$c(\AA)$ & 19.3754(13) & 19.369(13) \\
\hline$\alpha\left(^{\circ}\right)$ & $77.635(4)$ & $79.20(4)$ \\
\hline$\beta\left(^{\circ}\right)$ & $81.522(4)$ & $80.90(3)$ \\
\hline$\gamma\left({ }^{\circ}\right)$ & $85.307(5)$ & $84.40(4)$ \\
\hline$V\left(\AA^{3}\right)$ & $1974.2(2)$ & 1983(2) \\
\hline$Z$ & 1 & 1 \\
\hline Temperature (K) & $100(2)$ & $100(2)$ \\
\hline Wavelength $(\AA)$ & 0.71075 & 0.71073 \\
\hline $\begin{array}{l}\text { Calculated density } \\
\qquad\left(\mathrm{g} . \mathrm{cm}^{-3}\right)\end{array}$ & 1.155 & 1.193 \\
\hline $\begin{array}{l}\text { Absorption coefficient } \\
\qquad\left(\mathrm{mm}^{-1}\right)\end{array}$ & 0.354 & 0.36 \\
\hline
\end{tabular}




\begin{tabular}{|c|c|c|}
\hline $\begin{array}{l}\text { Transmission factors } \\
\text { (min./max.) }\end{array}$ & 0.479 and 1.000 & 0.796 and 1.000 \\
\hline Crystal size $\left(\mathrm{mm}^{3}\right)$ & $0.04 \times 0.03 \times 0.01$ & $0.07 \times 0.04 \times 0.02$ \\
\hline$\theta(\max )\left(^{\circ}\right)$ & 25.0 & 22.5 \\
\hline Reflections measured & 21387 & 17204 \\
\hline Unique reflections & 6954 & 5167 \\
\hline$R_{\text {int }}$ & 0.1230 & 0.072 \\
\hline $\begin{array}{l}\text { Reflections with } F^{2}> \\
2 \sigma\left(F^{2}\right)\end{array}$ & 2929 & 3631 \\
\hline Number of parameters & 477 & 527 \\
\hline$R_{1}\left[F^{2}>2 \sigma\left(F^{2}\right)\right]$ & 0.0896 & 0.105 \\
\hline$w R_{2}$ (all data) & 0.2555 & 0.282 \\
\hline GOOF, $S$ & 0.968 & 1.11 \\
\hline $\begin{array}{l}\text { Largest difference } \\
\text { peak and hole (e } \AA^{-3} \text { ) }\end{array}$ & 0.399 and -0.398 & 0.55 and -0.754 \\
\hline
\end{tabular}

Table 6 con't. Crystallographic data for the complexes $6 \cdot 4$ toluene, 7 and 8

\begin{tabular}{|c|c|c|c|}
\hline Compound & 6.4toluene & 7 & 8 \\
\hline Formula & $\mathrm{C}_{114} \mathrm{H}_{132} \mathrm{~N}_{2} \mathrm{Cl}_{2} \mathrm{~V}_{2} \mathrm{O}_{6} \cdot 4 \mathrm{C}_{7} \mathrm{H}_{8}$ & $\mathrm{C}_{86} \mathrm{H}_{110} \mathrm{~N}_{2} \mathrm{Cl}_{2} \mathrm{~F}_{6} \mathrm{~V}_{2} \mathrm{O}_{6}$ & $\mathrm{C}_{76} \mathrm{H}_{106} \mathrm{~V}_{2} \mathrm{O}_{8}$ \\
\hline Formula weight & 1798.99 & 1554.53 & 1249.49 \\
\hline Crystal system & triclinic & triclinic & triclinic \\
\hline Space group & $P \overline{1}$ & $P \overline{1}$ & $P \overline{1}$ \\
\hline \multicolumn{4}{|c|}{ Unit cell dimensions } \\
\hline$a(\AA)$ & $10.8048(12)$ & $10.5705(7)$ & $11.3476(8)$ \\
\hline$b(\AA)$ & $14.4744(13)$ & 11.3001(8) & $12.2819(19)$ \\
\hline$c(\AA)$ & 18.3207(19) & $17.4045(11)$ & $16.8097(11)$ \\
\hline
\end{tabular}




\begin{tabular}{|c|c|c|c|}
\hline$\alpha\left(^{\circ}\right)$ & 74.937(8) & 94.986(7) & $100.861(4)$ \\
\hline$\beta\left(^{\circ}\right)$ & $84.606(9)$ & $90.688(7)$ & $99.097(4)$ \\
\hline$\gamma\left({ }^{\circ}\right)$ & 69.796(8) & $93.257(7)$ & $108.087(5)$ \\
\hline$V\left(\AA^{3}\right)$ & 2596.5(5) & $2067.4(2)$ & 2127.4(3) \\
\hline$Z$ & 1 & 1 & 1 \\
\hline Temperature (K) & $150(2)$ & $100(2)$ & $100(2)$ \\
\hline Wavelength $(\AA)$ & 0.71073 & 0.71075 & 0.71073 \\
\hline $\begin{array}{l}\text { Calculated density } \\
\qquad\left(\text { g.cm }{ }^{-3}\right)\end{array}$ & 1.151 & 1.249 & 0.975 \\
\hline $\begin{array}{c}\text { Absorption } \\
\text { coefficient }\left(\mathrm{mm}^{-1}\right)\end{array}$ & 0.284 & 0.356 & 0.263 \\
\hline $\begin{array}{l}\text { Transmission factors } \\
\text { (min./max.) }\end{array}$ & 0.786 and 0.818 & 0.688 and 1.00 & 0.9818 and 0.9921 \\
\hline Crystal size $\left(\mathrm{mm}^{3}\right)$ & $0.40 \times 0.25 \times 0.20$ & $0.07 \times 0.06 \times 0.01$ & $0.07 \times 0.06 \times 0.03$ \\
\hline$\theta(\max )\left(^{\circ}\right)$ & 25.328 & 27.486 & 27.49 \\
\hline $\begin{array}{c}\text { Reflections } \\
\text { measured }\end{array}$ & 18331 & 25769 & 9683 \\
\hline Unique reflections & 9342 & 9232 & 9683 \\
\hline$R_{\text {int }}$ & 0.0776 & 0.0763 & 0.059 \\
\hline $\begin{array}{l}\text { Reflections with } F^{2}> \\
2 \sigma\left(F^{2}\right)\end{array}$ & 3813 & 5672 & 6948 \\
\hline $\begin{array}{l}\text { Number of } \\
\text { parameters }\end{array}$ & 525 & 469 & 392 \\
\hline$R_{1}\left[F^{2}>2 \sigma\left(F^{2}\right)\right]$ & 0.0652 & 0.0942 & 0.0566 \\
\hline$w R_{2}$ (all data) & 0.1661 & 0.2885 & 0.1587 \\
\hline GOOF, $S$ & 0.785 & 1.037 & 1.057 \\
\hline $\begin{array}{l}\text { Largest difference } \\
\text { peak and hole (e } \AA^{-3} \text { ) }\end{array}$ & 0.510 and -0.303 & 1.376 and -0.568 & 0.631 and -0.502 \\
\hline
\end{tabular}




\section{References}

[1] (a) R. Galletti and G. Pampaloni, Coord. Chem. Rev. 2010, 254, 525-536. (b) K. Nomura and W. Zhang, Chem Sci. 2010, 1, 161-173. (c) Y. R. Patil in: Olefins Polymerization Reactivity of Niobium-Based Metal Complexes, US, Lambert Academic Publishing, 2011. (c) D. Wang, Z. Zhao, T. B. Mikenas, X. Lang, L. G. Echevskaya, C. Zhao, M. A. Matsko and W. Wu, Polym. Chem. 2012, 3, 2377-2382.

[2] See for example (a) H. Hagen, J. Boersma and G. van Koten, Chem. Soc. Rev. 2002, 31, 357364. (b) S. Gambarotta, Coord. Chem. Rev. 2003, 237, 229-243. (c) Y. Onishi, S. Katao, M. Fujiki and K. Nomura, Organometallics 2008, 27, 2590-2596. (d) J.Q. Wu, L. Pan, N. H. Hu and Y. S. Li, Organometallics 2008, 27, 3840-3848. (e) C. Redshaw, Dalton Trans. 2010, 39, 55955604 and references therein.

[3] (a) D. Takeuchi, Dalton Trans. 2010, 39, 311-328. (b) K. Nomura and W. Zhang, Chem. Rev. 2011, 111, 2342-2362. (c) J. -Q. Wu and Y. -S. Li, Coord. Chem. Rev. 2011, 255, 2303-2314. (d) S. W. Zhang, L. -P. Lu, B. -X. Li and Y. -S. Li, J. Polym. Sci. A, Polym. Chem. 2012, 50, 47214731. (e) S. W. Zhang, L. -P. Lu, Y. -Y. Long and Y. -S. Li, J. Polym. Sci. A, Polym. Chem. 2013, 51, 844-854. (f) L. -P. Lu, J. -B. Wang, J. -Y. Liu and Y. -S. Li, J. Polym. Sci. A, Polym. Chem. 2014, 52, 2633-2642.

[4] (a) C. Redshaw, L. Warford, S. H. Dale and M. R. J. Elsegood, Chem. Comm. 2004, 19541956. (b) C. Redshaw, M. A. Rowan, D. M. Homden, S. H. Dale, M. R. J. Elsegood, S. Matsui and S. Matsuura, Chem. Comm. 2006, 3329-3331. (c) C. Redshaw, M. A. Rowan, L. Warford, D. M. Homden, A. Arbaoui, M. R. J. Elsegood, S. H. Dale, T. Yamato, C. P. Casas and S. Matsui, Chem. Eur. J. 2007, 13, 1090-1107. (d) D. M. Homden, C. Redshaw, L. Warford, D. L. Hughes, J. A. Wright, S. H. Dale and M. R. J. Elsegood, Dalton Trans. 2009, 8900-8910. (e) C. Redshaw, D. M. Homden, D. L. Hughes, J. A. Wright and M. R. J. Elsegood, Dalton Trans. 2009, 12311242. (f) L. Clowes, C. Redshaw and D. L. Hughes, Inorg. Chem. 2011, 50, 7838-7845. (g) C. Redshaw, L. Clowes, D. L. Hughes, M. R. J. Elsegood and T. Yamato, Organometallics 2011, 30, 5620-5624. (h) C. Redshaw, M. J. Walton, D. S. Lee, C. Jiang, M. R. J. Elsegood and K. Michiue, Chem. Eur. J. 2015, 21, 5199-5210. (i) C. Redshaw, M. J. Walton, K. Michiue, Y. 
Chao, A. Walton, P. Elo, V. Sumerin, C. Jiang and M. R. J. Elsegood, Dalton Trans. 2015, 44, 12292-12303.

[5] L.H. Tang, E. P. Wasserman, D. R. Neithamer, R. D. Krystosek, Y. Cheng, P. C. Price, Y. Y. He and T. J. Emge, Macromolecules 2008, 41, 7306-7315.

[6] J. Zhang, C. Jian, Y. Gao, L. Wang, N. Tang and J. Wu, Inorg. Chem. 2012, 51, 13380-13389.

[7] Y. Al-Khafaji, X. Sun, T. J. Prior, M. R. J. Elsegood and C. Redshaw, Dalton Trans. 2015, 44, 12349-12356.

[8] A.G. Fisch, J. N. da Silveira, N. S. M. Cardozo, A. R. Secchi, J. H. Z. dos Santos and J. B. P. Soares, J. Mol. Cat A Chem. 2013, 366, 74-83.

[9] R. E. LaPointe, J. C. Stevens, P. N. Nickias and M. H. McAdon, Dow Chemicals USA, EP 0 520732 B1, 1992.

[10] (a) R. Figueroa, R. D. Froese, Y. He, J. Klosin, C. N. Theriault and K. A. Abboud, Organometallics 2011, 30, 1695-1709. (b) P. P. Fontaine, R. Figueroa, S. D. McCann, D. Mort and J. Klosin, Organometallics 2013, 32, 2963-2972. (c) T. R. Boussie, G. M. Diamond, C. Goh, K. A. Hall, A. M. LaPointe, M. K. Leclerc, V. Murphy, J. A. W. Shoemaker, H. Turner, R. K. Rosen, J. C. Stevens, F. Alfano, V. Busico, R. Cipullo and G. Talarico, Angew. Chem. Int. Ed. 2006, 45, 3278-3283. (d) P. S. Chum and K. W. Swogger, Prog. Polym. Sci. 2008, 33, 797-819. (e) For a recent review on the use of Post-Metallocenes catalysts for industrial polyolefin production, see M. C. Baier, M. A. Zuideveld and S. Mecking, Angew. Chem. Int. Ed. 2014, 53, 9722-9744.

[11] (a) N. Desmangles, S. Gambarotta, C. Bensimon, S. Davis and H. Zahalka, J. Organomet, Chem. 1998, 562, 53-60. (b) Y. Ma, D. Reardon, S. Gambarotta and G. Yap, Organometallics 1999, 18, 2773. (c) H. Hagen, J. Boersma, M. Lutz, A. L. Spek and G. van Koten, Eur. J. Inorg. Chem. 2001, 117. (d) M. Arndt-Rosenau, M. Hoch, J. Sundermeyer, J. Kipke and X. Li, US Pat. 01 304551, 2003. (e) Y. Nakayama, H. Bando, Y. Sonobe and T. Fujita, J. Mol. Catal. A: Chem. 2004, 213, 141. (f) S. Cuomo, S. Milione and A. Grassi, J. Polym, Sci., Part A: Polym. Chem. 2006, 44, 3279. (g) S. Zhang, W. -C. Zhang, D.-D. Shang, Z. -Q. Zhang, and Y. -X. Wu, Dalton Trans. 2015, DOI 10.1039/c5dt00675a 
[12] See for example (a) C. R. Randall and W. H. Armstrong, J. Chem. Soc., Chem. Commun. 1988, 986-987. (b) G. Asgedom, A. Sreedhara, J. Kivikoski, E. Kolehmainen and C. P. Rao, J. Chem. Soc., Dalton Trans. 1996, 93-97.

[13] (a) M. Mazzanti, C. Floriani, A. Chiese-Villa and C. Guastini, J. Chem. Soc., Dalton Trans. 1989, 1793-1798. (b) P. J. Toscano, E. J. Schermerhorn, C. Dettelbacher, D. Macherone and J. Zubieta, J. Chem. Soc., Chem. Comm. 1991, 933-934.

[14] (a) W. Clegg, M. R. J. Elsegood, S. J. Teat, C. Redshaw and V. C. Gibson, J. Chem. Soc., Dalton Trans. 1998, 3037-3040. (b) W. Clegg, J. Chem. Soc., Dalton Trans. 2000, 3223-3232.

[15] (a) C. Redshaw in Olefin Upgrading Catalysis by Nitrogen-based Metal Complexes I, Eds. G. Giambastini and J. Cámpora, Springer 2011. (b) S. Zhang and K. Nomura, Catal Surv Asia 2011, 15, 127-133.

[16] (a) E. A. Maatta, Inorg. Chem. 1984, 23, 2561-2562. (b) D. D. Devore, J. D. Lichtenhan, F. Takusagawa and E. A. Maatta, J. Am. Chem. Soc. 1987, 109, 7408-7416.

[17] F. H. Allen, Acta Crystallogr. Sect. B: Struct. Sci., 2002, 58, 380-388.

[18] Spiro compounds related to motif I in the CSD: (a) A. M. Litwak, F. Grynazpan, O. Aleksiuk, S. Cohen and S. E. Biali, J. Org. Chem. 1983, 58, 393-402. (b) F. Grynszpan and S. E. Biali, J. Chem. Soc., Chem. Commun. 1994, 2545-2546. (c) O. Aleksiuk, S. Cohen and S. E. Biali, J. Am. Chem. Soc.1995, 117, 9645-9652. (d) F. Grynszpan and S. E. Biali, J. Org. Chem. 1996, 61, 9512-9521. (e) J. Wöhnert, J. Brenn, M. Stoldt, O. Aleksiuk, F. Grynszpan, I. Thondorf and S. E. Biali, J. Org. Chem. 1998, 63, 3866-3874. (f) K. Agharia, O. Aleksiuk, S. E. Biali, V. Böhmer, M. Frings and I. Thondorf, J. Org. Chem. 2001, 66, 2891-2899. (g) K. Agharia and S. E. Biali, J. Am. Chem. Soc. 2001, 123, 12495-12503.

[19] A. G. Maestri and S. N. Brown, Inorg. Chem. 2004, 43, 6996-7004.

[20] For early use of ETA, see (a) A. Gumboldt, J. Helberg and G. Schleitzer, Makromol. Chem. 1967, 101, 229-245. (b) D. L. Christman, J. Polym. Sci. Part A, 1972, 10, 471-487. (c) E. Addison, A. Deffieux, M. Fontanille and K. Bujadoux, J. Polym. Sci, Part A, 1994, 32, 1033-1041. 
[21] E. W. Hansen, R. Blom and O. M. Bade, Polymer 1997, 38, 4295-4304.

[22] W. Wang and K. Nomura, Macromolecules, 2005, 38, 5905-5913.

[23] E. Müller, A. Schick and R. Mayer, Chem. Ber. 1960, 93, 2649-2662.

[24] APCI refers to the ionization method, Atmospheric Pressure Chemical Ionization, in which samples introduced into the APCI source via an Atmospheric Solids Analysis Probe (ASAP) are vaporized then ionized using a corona discharge $(\sim 4 \mu \mathrm{A})$. The benefit of using ASAP is that samples can be introduced at ambient temperature as solids or in solution, then the temperature in the source is increased until the sample vaporizes.

[25] X-AREA v 1.64, STOE \& Cie GmbH, Darmstadt, 2012.

[26] G. Sheldrick, Acta Crystallogr. Sect. A: Found. Crystallogr. 2008, 64, 112-122.

[27] A. L. Spek, Acta Cryst. 2009, D65, 148-155.

[28] A. L. Spek, Acta Crystallogr. 1990, A46, C34. 